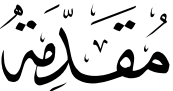

أحمد الله الذي بيده الحول و الطول، و أصلى و أسلم على صفوة خلقه وخاتم أنبيائه ورسله..

\section{و بعد:}

فمعرفة مصادر المادة العلمية ترشد إلى معرفة فكر صــاحبها، وجهــده،

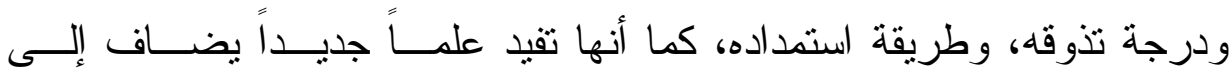

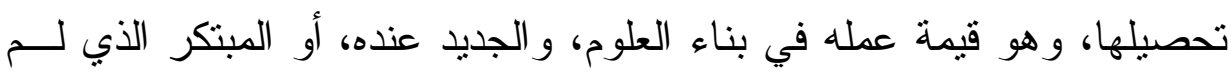
يسبق إليه...

و من خلال هذا العمل تبين أن ابن قتيبة استمد خو اطره، و أفكاره التـي شكلت عقله، وكونت علمه من مصدرين أساسيين:

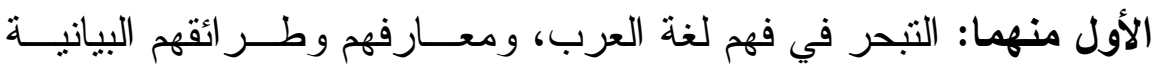
البارزة في شعر هم ونثز هم وحكمهم و أمثالهم.

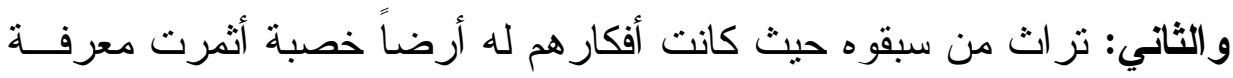

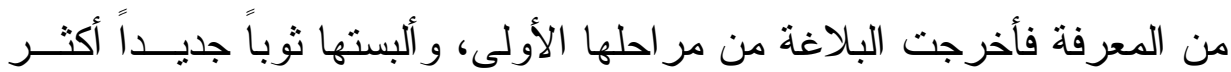

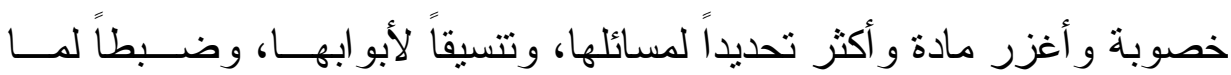
يستفاد من قو اعدها. فقد كان يأخذ الجزئيات التي أثنار إليها الجاحظ، و أبو عبيــدة، و الفــر اء، وبعض علماء اللغة، و علماء التفسير القدامى كابن عباس، ومجاهــد، وقتــادة، و الثوري، و الصنعاني ويستخر ج منها أصول مادتــه، دون اكتفـــاء بإثـــار اتهم و تلميحاتهم، بل كان يحرر ذللك ويوضحه، ويدعمه بالثو اهد، ويديره بطريقــة جديدة تخدم غرضه وتتاسب مر اده من هذا الكتاب. وقد أثنار في مقدمته إلى استناده على التفسير بزيادة في الثرح و الإيضاح 


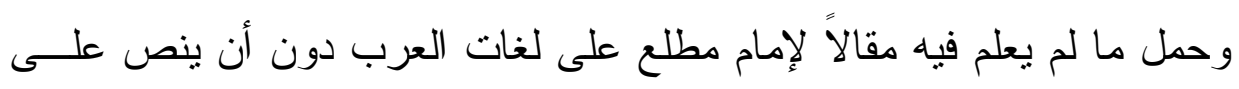
من له أصل التفسير معلاً ذلك بقوله اإذ كنت لم أقتصر على وحى القوم حتى على كثفته، و على إيمائهم حتى أوضحته وزدت في الألفاظ ونقصت وقدمت و أخرت

وضربت لذلك الأمثال و الأشكال حتى يستوي في فهمه السامعونه"(1). ففي هذه الكلمة بناء منهج وطريقة معالجة و إثنارة إلى إعمال الفكر و العقل

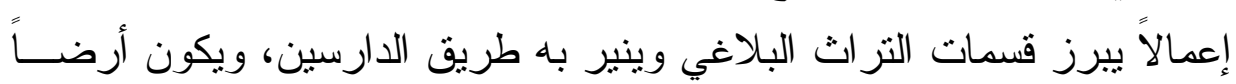
لمن جاءو ا بعده، ومهاداً لفكر هم.

وقد أردت بهذا العمل الموجز بيان أصول معرفته ومنابتها، و الطريقة التي

عليها نبتت و المدى الذي إليه وصلت، وذللك من خلال الرجوع بــالفكرة إلـى لـى التز اث و عرضها عليه حتى يتجلى كيف تعامل معه وكيف استتبط منه وهل سلم

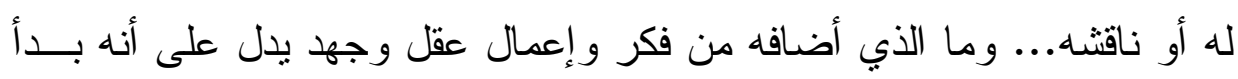
من حيث انتهى غيره بعد فهم وتذوق لكلام غيره، ولم أتغافل ما جاد به فيه فكره

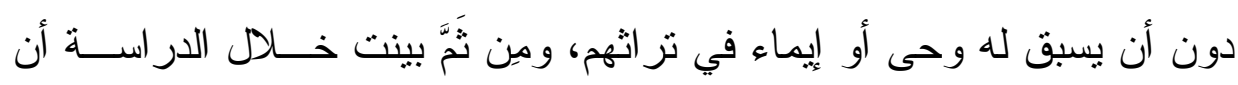

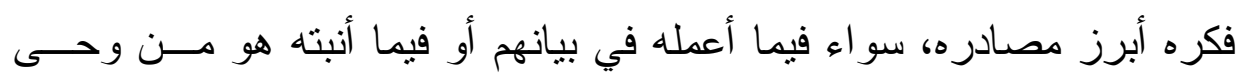

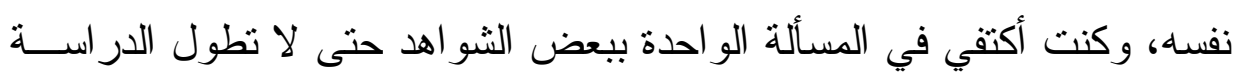
وتخرج عن غرضها وليس فيما تركته من شواهد مصدر جديد عما ذكرته، بل

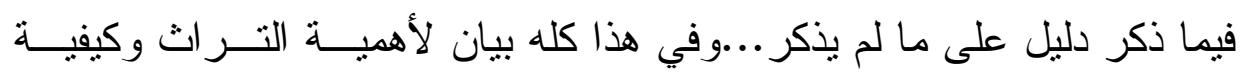
التعامل معه و الإفادة منه.

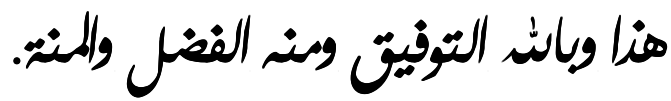

\section{أ.د. السيد هممد سلام}

(1) تأويل مشكل القر آن بr، شرحه و نشره: السيد أحمد صقر - المكتبة العلمية، بيروت -

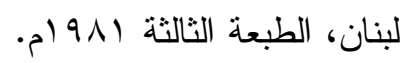




\section{نكر ابن تتيبة بين التزاث}

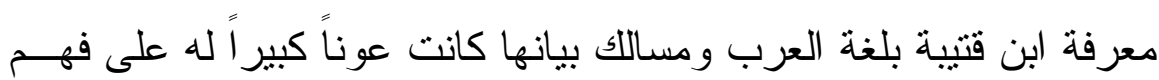

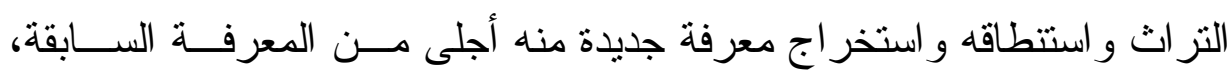
و أكثر جمعاً، وتحديداً لأبو اب البلاغة التي تناثرت في بيان من سبقوه، ومسنـ استقى منهم رو افد علمه.

فالمسائل البلاغية التي وقف عندها كائنة في بيان سلفه، ولكنها جاءت بين ثنايا عملهم إثنار ات موجزة ولمحات دقيقة تحتاج إلى ثبيان، كصنيع أبى عبيدة

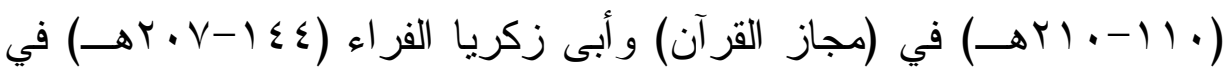

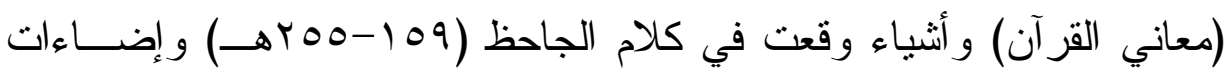
المفسرين.

كهِ وقد وقف ابن قتيبة عند ذلك بصياغة أخرى تجمع قدر اً مــن مســئل البلاغة، وتُكْثر من شو اهدها بحيث تتغازر لديه المادة وتصبر له، وكأنها مسن جهده خالصة، وبر اعة العالم تتجلى حين يغرق ما يأخذ في أفكار من عنده. و بذلك تبرز مو اقفه وتضفي معارفه على التراث نوعاً آخر من التصنيف يعالج

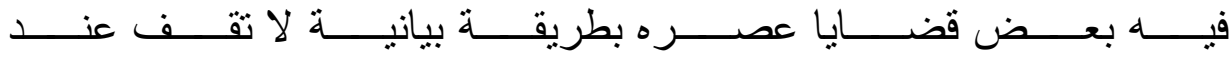
معاني الكلمات أو بيان الغريب فيها، فذللك عنده له عمل آخر أثنار إليـــه فـي (تأويل مشكل القرآن) بقوله: اوأفردت للغريب كتاباً؛ كي لا يطول هذا الكتاب؛

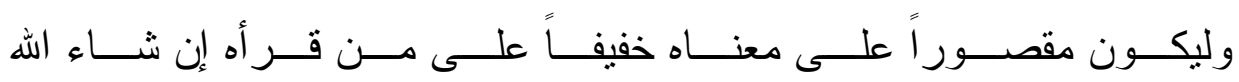
تعالى" (1)

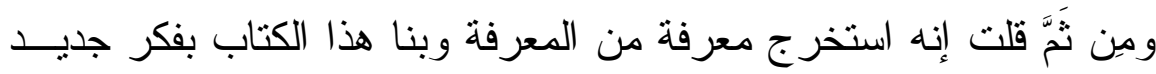
وصياغة جديدة ليست في مصادره و إن كانت مستمدة من مادتها. 


\section{الأستاذ الدكتور / السيد محمد السيد سلام}

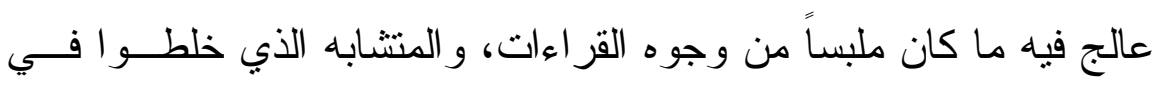

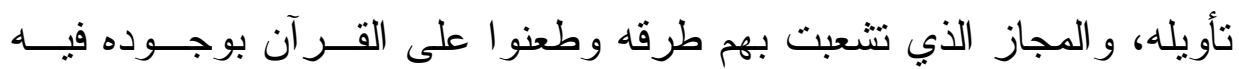
لز عمهم أنه كذب.

أنثار إلى هذه المو اقف، و عرض أفكار أصحابها، وردّ على ما ر آه فيها من تكلف و غموض، وبيَّن ما فيها من تأويل صحيح...

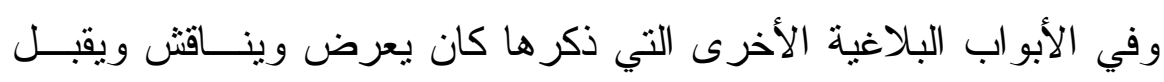
ويرفض ويستشهد بشعر العرب ونثر هم على ما يقول. يرى المتأمل ذلك في أبواب:

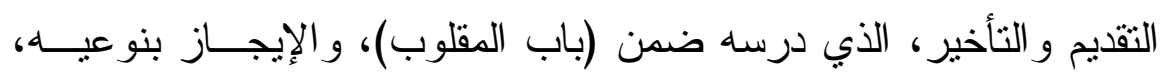

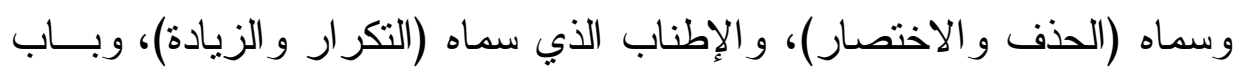
خروج الكلام على مقتضى الظاهر ، الذي سماه (مخالفة ظاهر اللفظ معناه). في كل ذللك له فكر خاص يُحسب له، وفكر قائم على كلام السابقين، أثنار

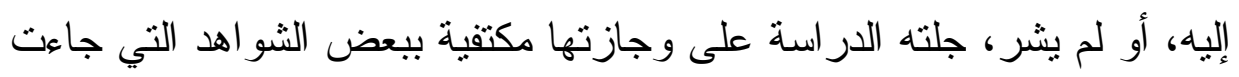
دليلاً على غير ها في (معرفة مصادره البلاغية).

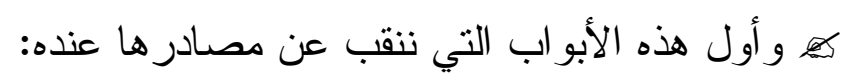

\section{(باب القول في الاماز)}

ذاك الذي تأثر فيه بكتاب (مجاز القرآن) لأبى عبيدة.

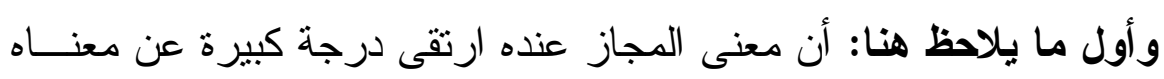

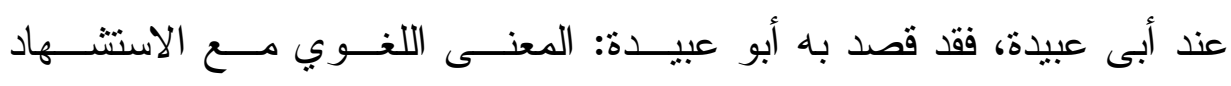
باستعمالات العرب.

أما ابن قتيبة: فقد رأى أنه يتسع لكل ألوان البلاغة وطرق التعبير ومسالك الأقو ال، فعرفه في هذا الكتاب بقوله: لاو للعرب المجاز ات في الكلام ومعناها: 
طرق القول ومآخذه، ففيها الاستعارة، و التمثيل، و القلب، و التقـــيم و التــأخير ،

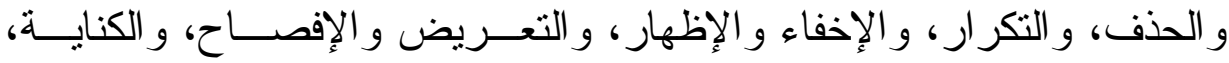
و الإيضاح، ومخاطبة الو احد مخاطبة الجميع، و الجميع خطاب الو احد، و الواحد و الجميع خطاب الاثثين، و القصد بلفظ الخصوص لمعنى العموم، وبلفظ العموم

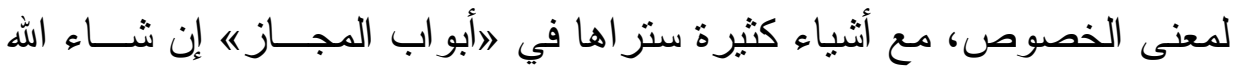
تعالى، وبكل هذه المذاهب نزل القر آن... (1)

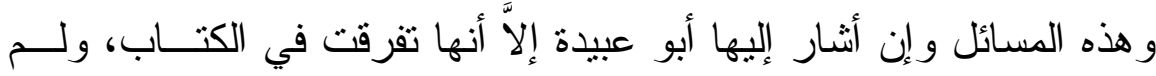
تدرس بهذه الكيفية التي جمعها عليها ابن قتيبة؛ حيث جعلها أبو اباً، وبين بلاغة إنة كل و احد منها في ضوء شو اهده، ومِن ثََّّ يتجلى أنه استخر جه من علم القوم فناً جديداً، وبدأ من حيث انتهى غيره، ولم يكرر في هذا الكتاب طريقتهه، و إن بنا

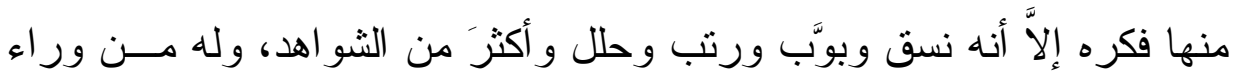

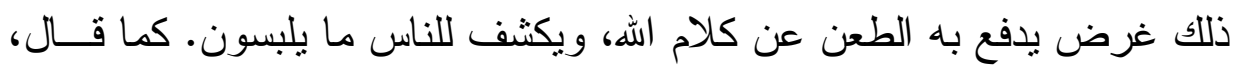

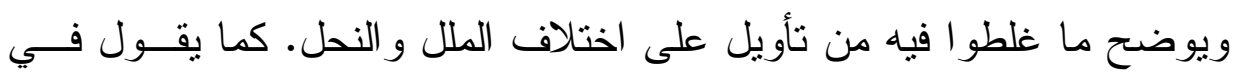

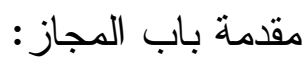

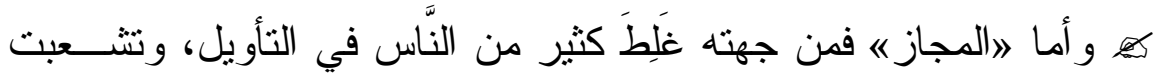
بهم الطرق و اختلفت النحل... «) وهو يقصد هنا بيان المشكل الذي أوقع في اللــب، و أدى إلــى الـــوهم،

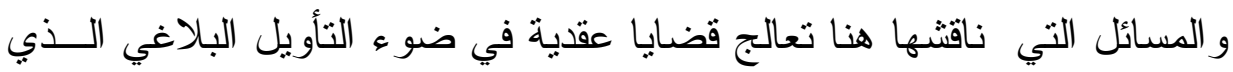
يكثف الحقيقة، ويزيل اللبس كمسألة 》التتاسخه التي اختلفو ا فيها من خلال بيان

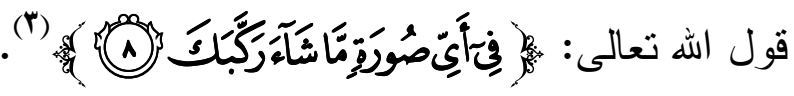

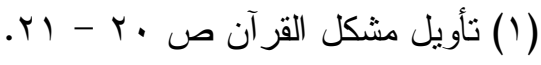

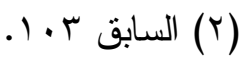

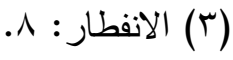


وسأعرض كلامه أولاً ثُ أكثف مصدره فيه وكيف عالجه.

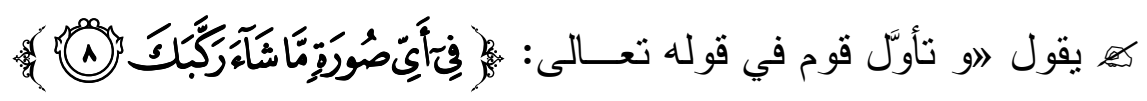
(سورة الانفطار : ^) معنى 》التتاسخه، ولم يرد الله في هذا الخطاب إنساناً بعينه

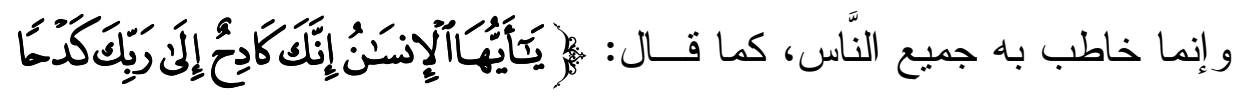

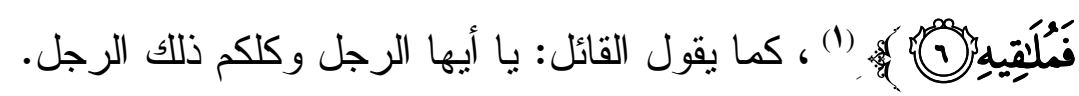

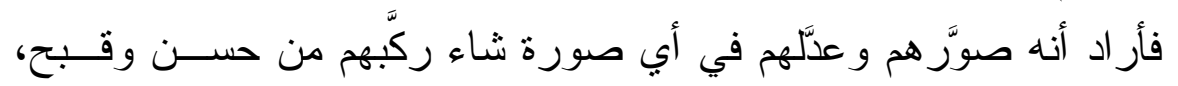

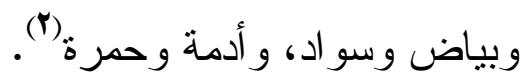

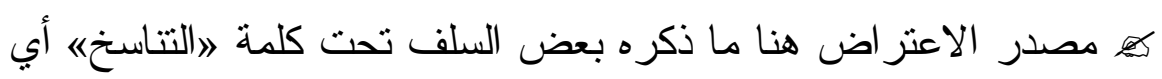
التبديل و التحويل.. وموجز بيانهم المذكور في هذه الآية: ما شاء ركبك أي: في صورة كلب وإن شاء في صورة حمار ، وقيل: إن شاء في صورة قرد.. ونحو

ذلك... (ז)

كيُّ أما مصدر جو ابه، فقد عقب بقوله: 》و لم برد الله إنساناً بعينهه و أفــاد

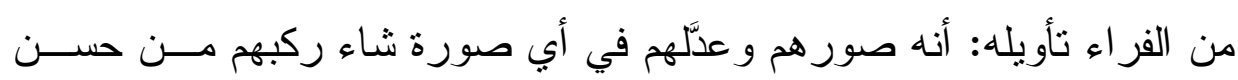
وقبح...... (ع)

فهذا إثنكال رآه في تأويل الآية وجمعه تحت كلمة 》التتاسخه وجلاه بمــا

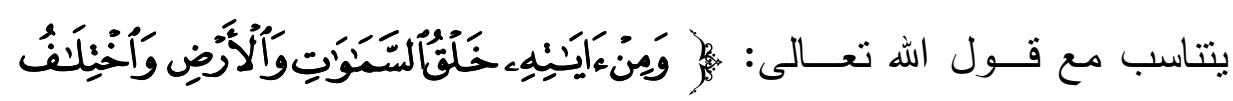

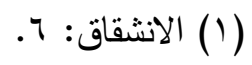

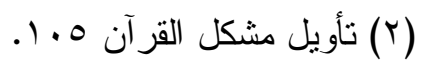

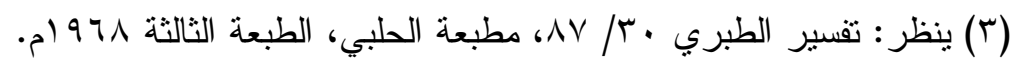

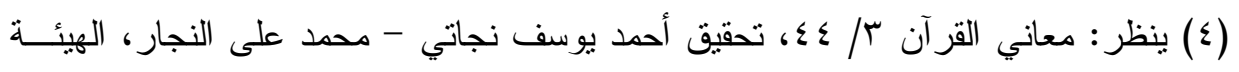
المصرية العامة للكتاب سنة . 191. 


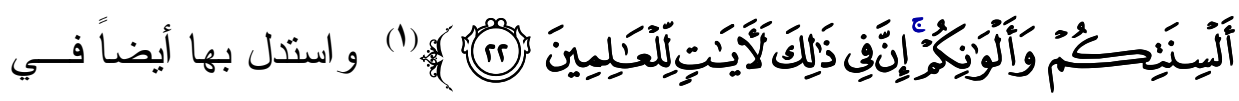

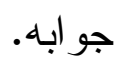

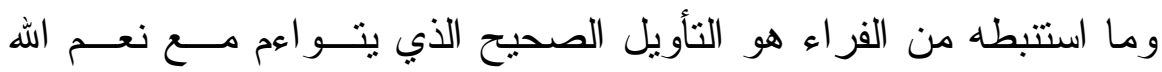

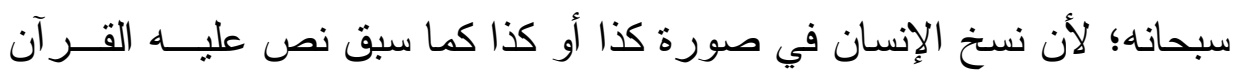

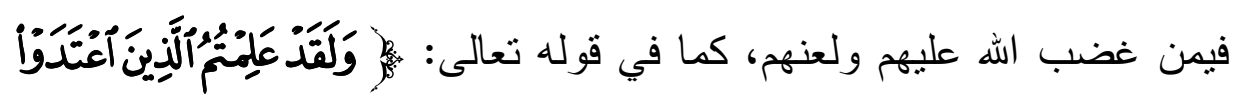

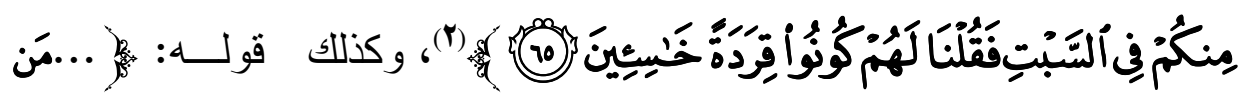

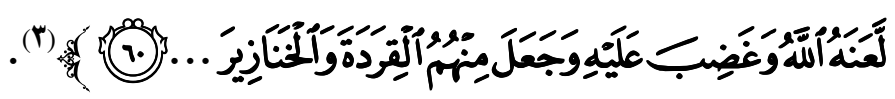

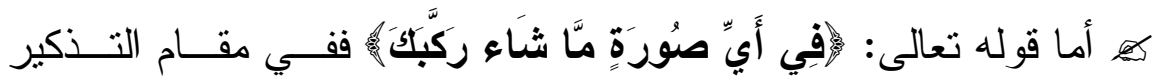

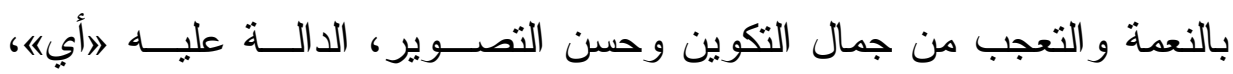
و لا يتتاسب معها هذا الذي دفعه ابن قتيبة سو اء من وحى نفسه أو من مصــدر بيانه، فقد عالج ما استتبطه بما يتتاسب مع السياق و المقام.

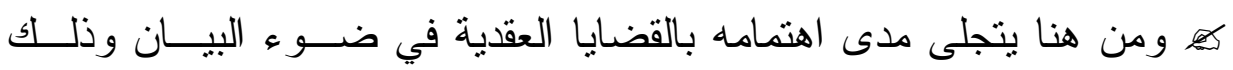

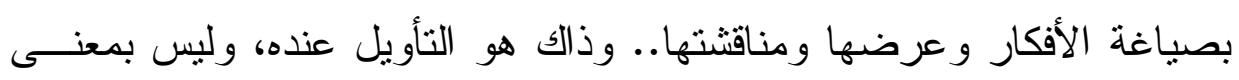

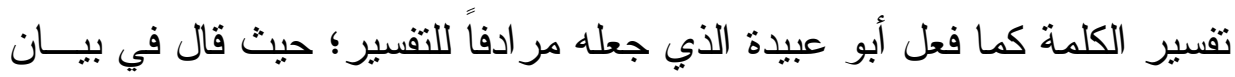

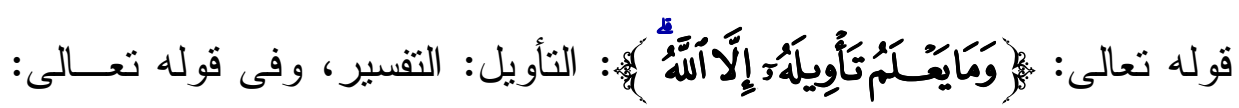

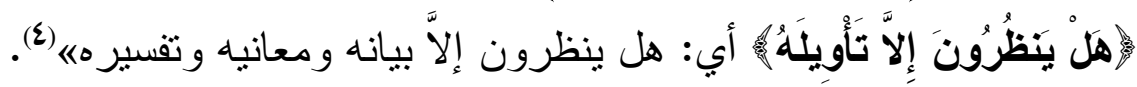

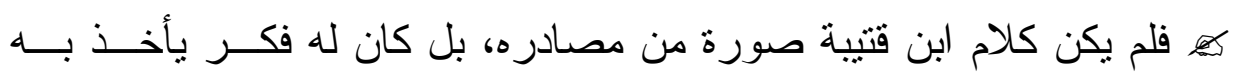

$$
\begin{aligned}
& \text { (1) الروم: بr. } \\
& \text { (Y) البقرة: } 0 .
\end{aligned}
$$

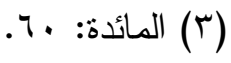

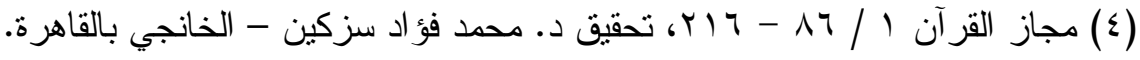


ويعارض ويناقش ويقبل ويرفض وينسق ويبوب، وهذا هو الجديد في عرضه،

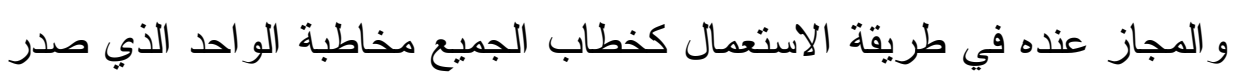

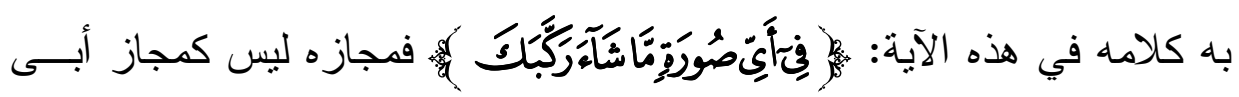
عبيدة؛ بل وضع ضابطاً بلاغياً من استعمالات العرب ونسج عليه تأويله، ولذا

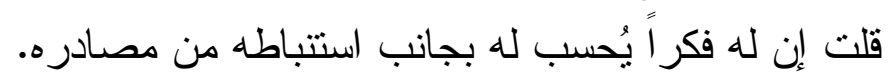
ومن أبرز المسائل التي عرضها في هذا الباب وناقثها و أفاد فيها من فكره وفكر غيره مسألة في: ت ونئ

\section{(الفرق بين المجاز في القول والماز في الكالمم)}

يقول: لاو ذهب قوم في قول الله وكلامه إلى أنه ليس قولاً و لا كلاماً على الحقيقة و إنما هو إيجاد للمعاني وصرفوه في كثثر من القرآن إلى المجاز كقول

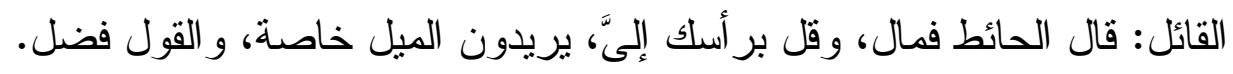

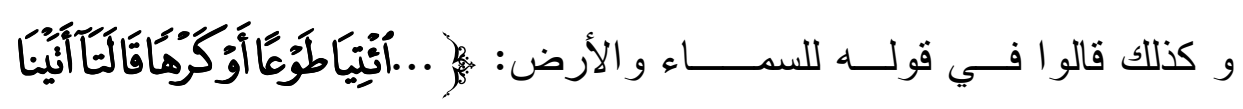

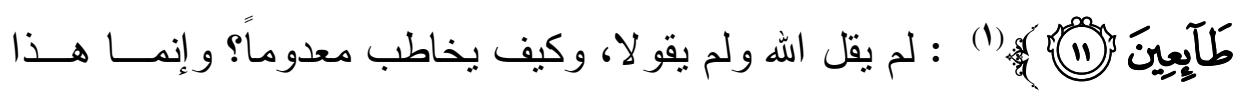
عبارة لكونَّاهُها فكانتا. قال الثاعر (المثقب العبدي) حكاية عن ناقته: تَقولُ إذا دَرَأتُ لَها وَضينين

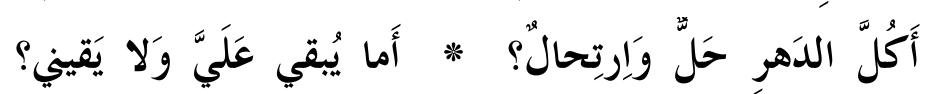

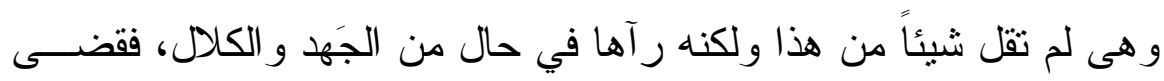

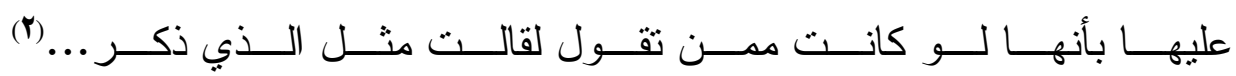

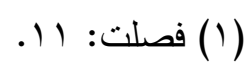

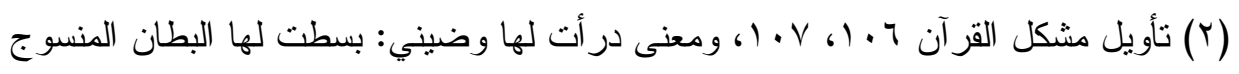
لتبرك و أثنده عليها. 
و غير ذلك من الشو اهد التي تجرى هذا المجرى.

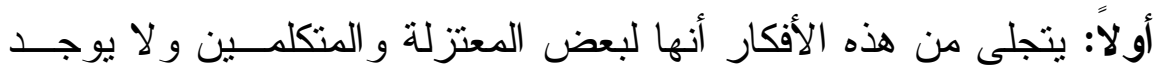

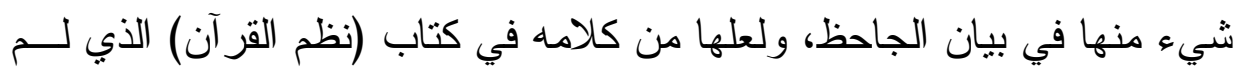
يصل إلينا، والذي أجمع العلماء على فقده ولكنها موجودة في كلام الزمخشري بعده(1)، ومعلوم أنه معتزلي..

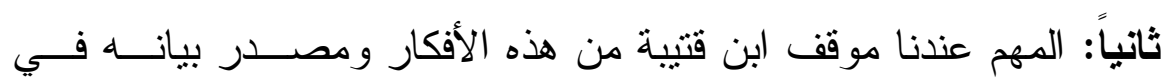
تأويلها.. ويتجلى هذا المصدر في أمرين: أولهما: العرف اللغوي الذي استمد منه معارفه، وكون منه عقله ليعـرف

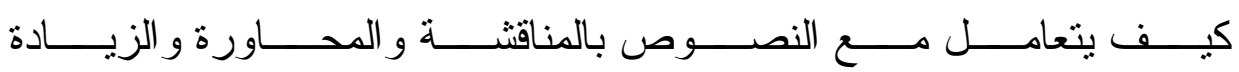

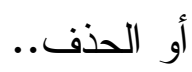

ثاتيهــــا: مجاز القر آن لأبى عبيدة، كان يأخذ منه إثـارته الموجزة بطريقة

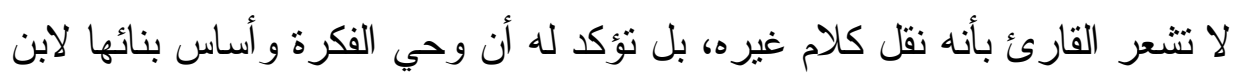
قتيبة وذللك لتوسعه فيما أخذه، و الإفادة منه في بيانه وشو اهده.

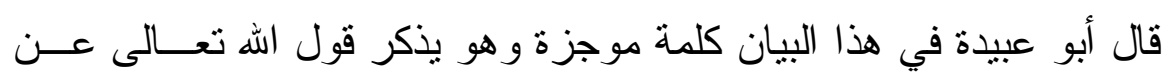

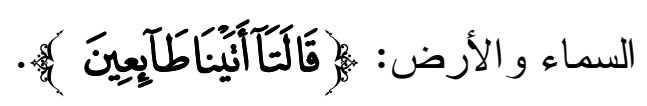

قال 》هذا مجاز الموات و الحيو ان الذي يشبه تقدير فعله بفعل الآدميينه(").

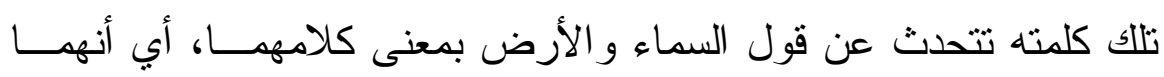
تكلمتا، و المجاز هنا في أنهما شبهتا بالأحياء الذين يتكلمون.

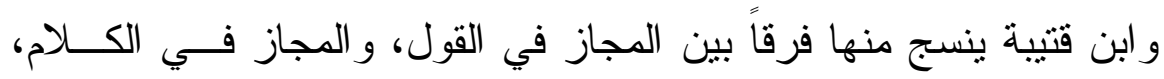

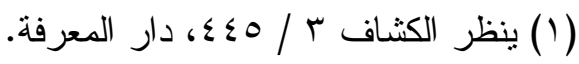

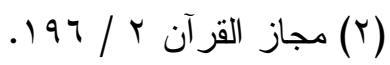




\section{الأستاذ الدكتور / السيد محمد السيد سلام}

بمعنى أنه يجوز : قال الحائط فيكون مجاز اً، ولا يصح أن أقول تكلم.... وتلــك لمحة دقيقة يقول فيها:

》اقال أبو محمد: وقد تبين لمن قد عرف اللغة أن القول يقع فيــهـ المجـــاز ،

فيقال: قال الحائط فمال، وقل بر أسك إلىَّ، أي أمله، وقالت الناقة وقال البعير . ولا يقال في مثل هذا المعنى: تكلم، و لا يعقل الكلام إلاَّ بالنطق بعينه، خلا موضع و احد، وهو أن تتبين في شيء من الموات عبرة ومو عظة، فتقول خبــر وتكلم وذكر ؛ لأنه دلّك معنى فيه فكأنه كلمك.... وهذا معنى أو تبيان كلمة أبى عبيدة السابقة وقد دعمها بكثير من الثو اهد لا يتسع المقال لذكرها حتى لا يحيد عن غرضه (معرفة المصدر ).

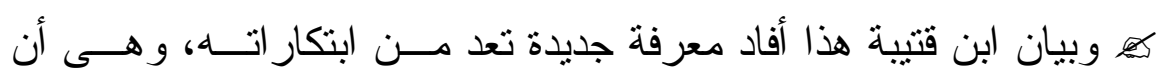
المجاز عنده يقع في قسمين:

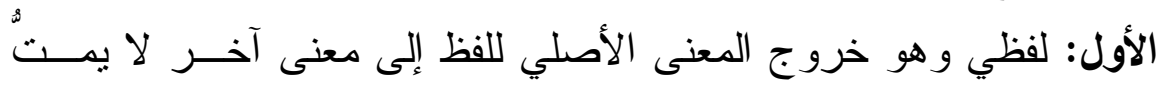
للأول بصلة، إنما هو التمانل في اللفظة، وذلك منل: قال الحائط، إذا مال.

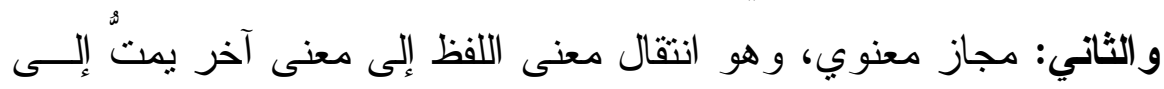

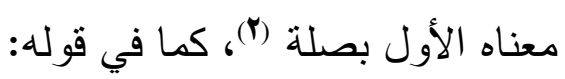
شكا إلىَّ جملي طولَ السرى

و الجمل لم يشكُ ولكن حالته تذل على ذلك ولو كان منكلماً لاشتكى، ونحو ذلك مما سبقت شو اهده. و تلك وقفة على طريقة استمداده من التراث تولد منها هذا التتويع للمجاز ،

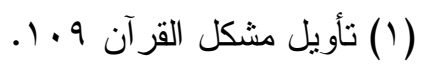

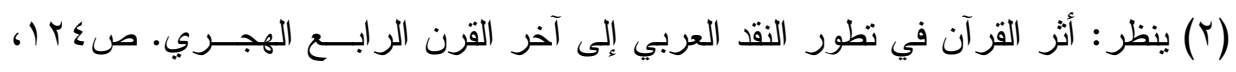

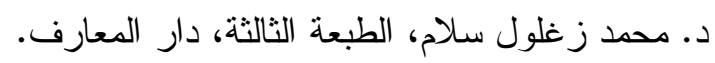


وهو جديد لم يسبق إليه.

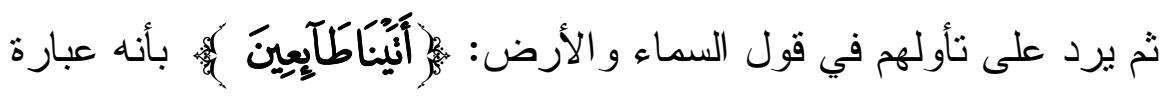

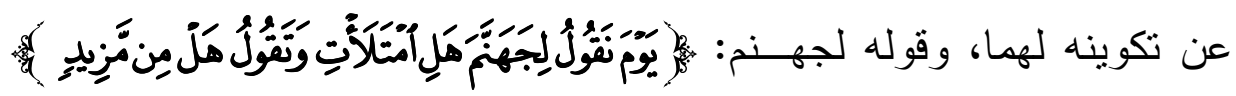
(ق: · r (r) إنه إخبار عن سعتها.

يرد على ذلك بقوله 》افما يحوج إلى التعسف و التماس المخـــار ج بالحيـلـل الضعيفة، وما ينفع من وجود ذلك في الآية و الآيتنن و المعنى و المعنيين، وسائر

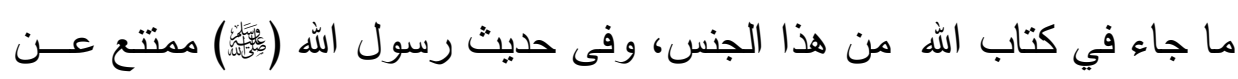
منتل هذه التأويلات.

وما فــي نطــق جهــنم ونطــق الســــاء و الأرض مــن العجــب؟ و الله

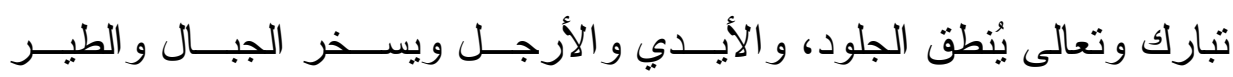

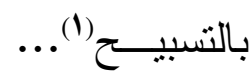

ويفهم من هذا: أنه لا يتكئ على مصادره فحسب؛ بل يولا من الفكر فكراً ومن القليل كثير اً لينى معرفة أوسع. وهو هنا لا يرتضى القول بالمجاز في منل هذه الثواهد ويرى أن الأولى ألى بها أن تجرى على الحقيقة، وتلك قضية عقدية زادها إيضاحاً في كتابه (اختلاف اللفظ و الرد على الجهمية و المشبهة).

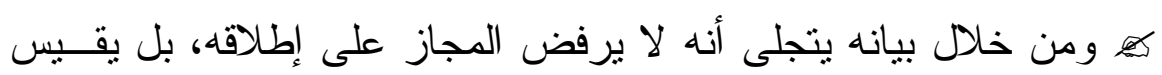

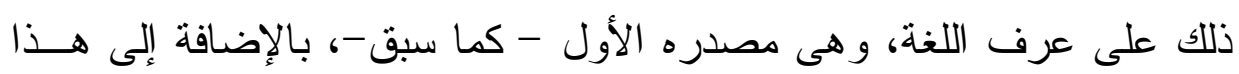
الاقتباس الذي يؤسس عليه معرفته حين يقبله. رده على الطاعنين في مجاز القرآن ومصدر فكره:

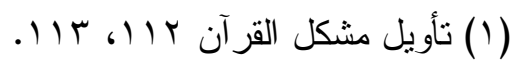




\section{الأستاذ الدكتور / السيد محمد السيد سلام}

مِن ثَمَّ بردّ على الطاعنين على القر آن بالمجاز ز اعمين بأنـــهـ كــذب، لأن

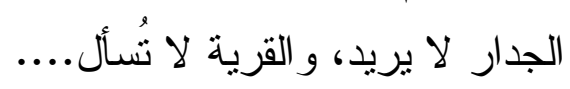

بأن هذا من أثنع جهالاتهم و أدلها على سوء نظر هُ هم وقلة أفهامهم. ثم يقول: ولو كان المجاز كذباً وكل فعل ينسب إلى غير الحيوان بـاطـانلاً كان أكثر كلامنا فاسداً لأنا نقول: نبت البقل، وطالت الثجرة، وأينعت الثرة وكة و أقام الجبل، ورخص السعر «"(1). كمُع ومصدر هذه الفكرة أيضاً نابع من التراث، وقد صر ح بذلك ها هنا في

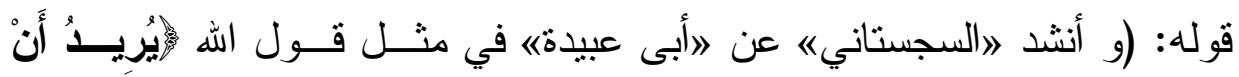

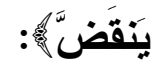

يريد الرمحُ صـــــدر أبي براءٍ * * ويرغبُ عن دماءِ بني عقيل و أنثد الفر اء:

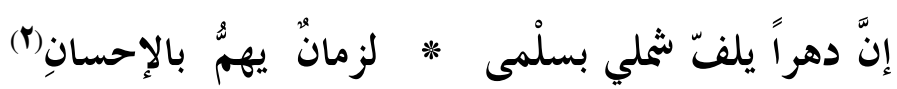

ونلحظ هنا أنه اكتفى بالثو اهد غير أن الفكرة نابعة من (مجــاز القـــــآن) لأبى عبيدة حين قال قبل ذكر الثاهد الذي تمثل به ابن فتيبة:

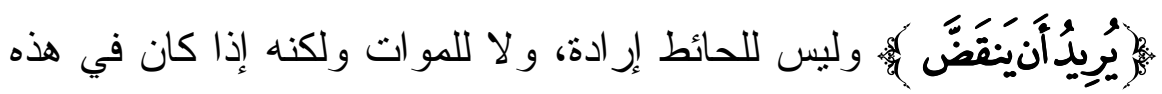
الحال من ربه فهو إر ادته، وهذا قول العرب: يريد الرمح(").... البيت.

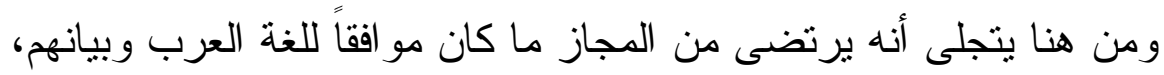

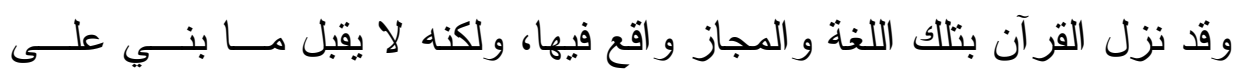

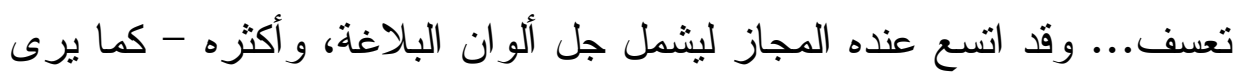

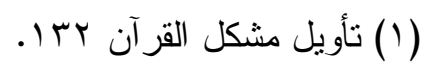

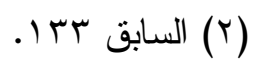

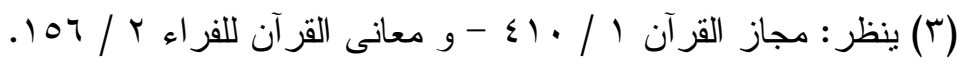




\section{(باب الاستمارة)}

و لذا بدأ بها بعد كلامه عن المجاز بصفة عامة.

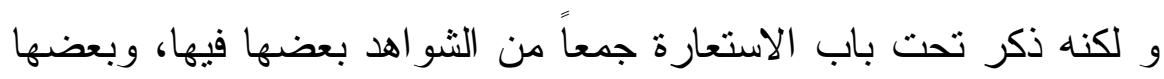
في المجاز المرسل، و الكناية و المشاكلة و المبالغة... و أطلق عليها الاستعارة من بن الاسنارة باب وضع كلمة مكان أخرى كما سيأني.

كيُّ ومصدره الأول فيها: كتاب: البيان و التبيين للجاحظ، وبعض إثنــار ات

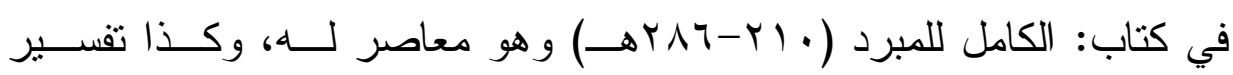

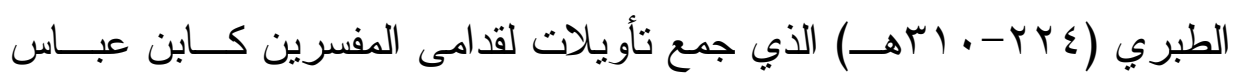
وقتادة.

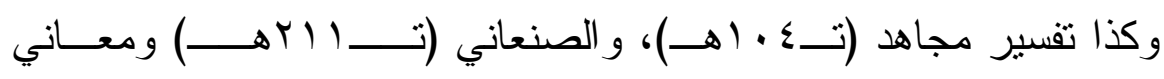

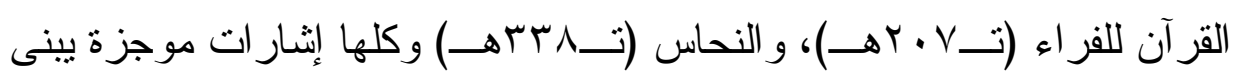

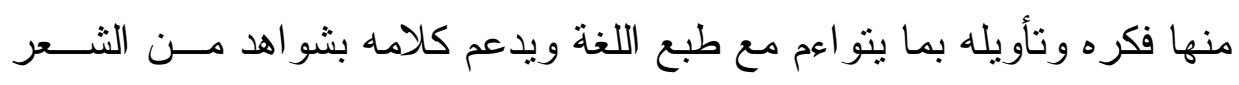

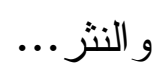

كيُّ قلت إن مصدره الأول في تحديد معنى الاستعارة هو الجاحظ وذللك في قوله تعقيباً على قول الثاعر:

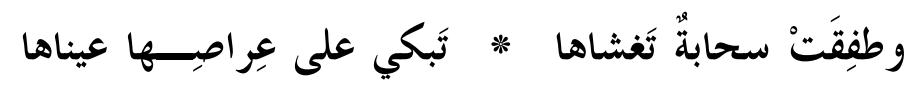

״عيناها《 ها هنا للسحاب، وجعل المطر بكاء من السحاب علــى طريـق الاستعارة، وتسمية الثيء باسم غيره إذا قام مقامهی) (1). تللك هي الإشتارة التي وردت في البيان و التبيين، ولم يذكر ها بهذا المعنـى

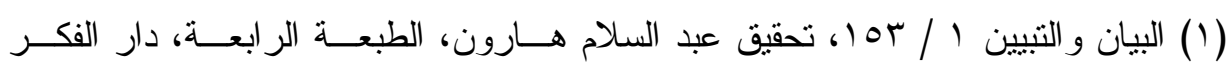
بيروت- لبنان. 


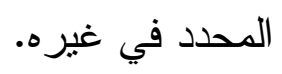

كيُه و هذا المعنى الذي ذكره الجاحظ يُعتبر ركيزة ابن قتيبة في هذا البــاب

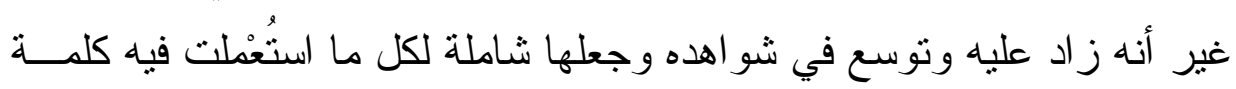
مكان غير ها.

ولذا عرف الاستعارة بقوله: الفالعرب تستعير الكلمة فتضعها مكان الكلمة

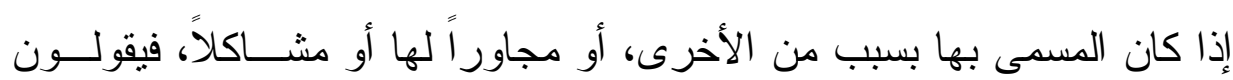

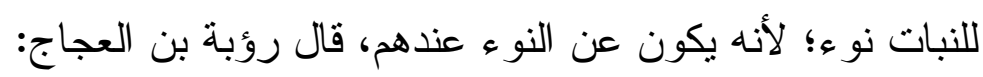
وجف أنواءُ السّحاب المرتزق عُّن

أي جف البقل، ويقولون للمطر سماء؛ لأنه من السماء ينزل، فيقال ما زلنا نطأ السماء حتى أتيناكم...ويقولون ضحكت الأرض إذا أنبتت؛ لأنها تبدى عن حسن النبات وتتفتق عن الزهر كما يفتر الضاحك عن الثغر ... «"(1). كل هذا و غيره من شو اهده الغزيرة في هذا الباب يعود مصدره إلى بيــان

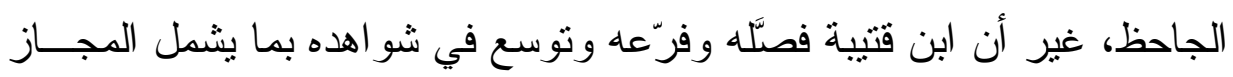

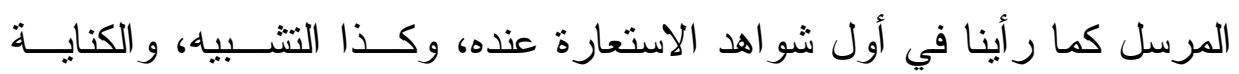
و المشاكلة، و هذا العموم موجود في كلمة الجاحظ أيضـاً، وذكر ابن قتيبـــة بــين

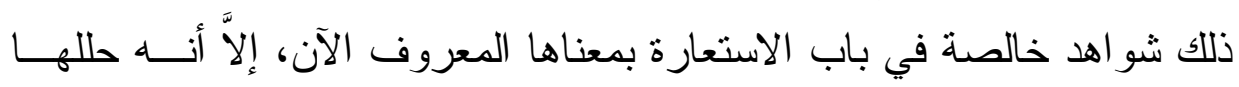

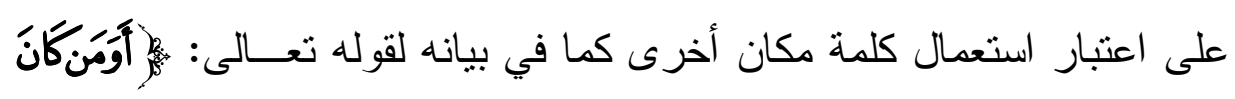

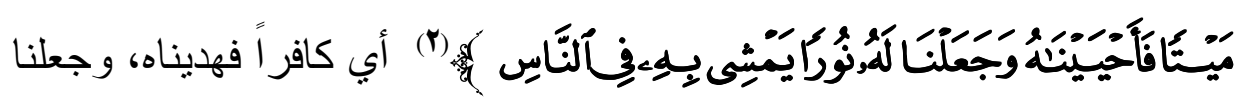

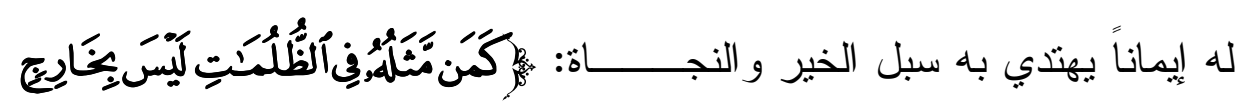




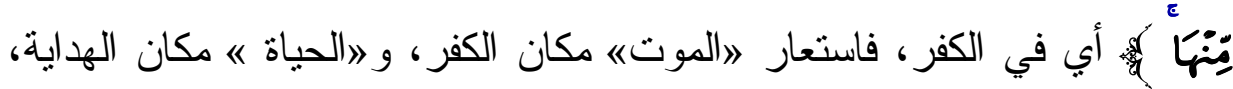

$$
\text { و 》النور 《) مكان الإيمان (1). }
$$

فهنا بيّن استعمال الكلمة مكان الأخرى لعلاقة بينهما ولقيامها مقامها، كمـــا

$$
\text { فعل الجاحظ في شاهده السابق. }
$$

ويتميز الجاحظ بتطبيق القاعدة التي ذكرها تطبيقــاً صـــحيحاً لا يخلطهــا

$$
\text { بغير ها من ألوان البلاغة الأخرى. }
$$

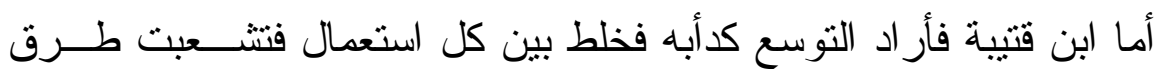
الاستعارة عنده كما تشعبت طرق المجاز من قبل في تعريفه له.

\section{ابن قنيبة يخالفع مصادره في جمل الكناية مر|دفة للإسنعارة:}

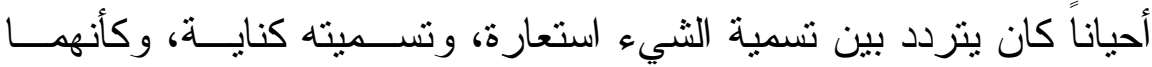

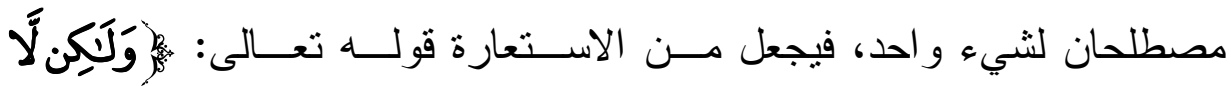

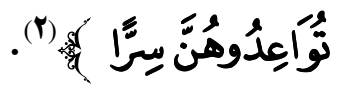

فيقول: أي نكاحاً؛ لأن النكاح يكون سراً، ولا يظهر فاستعير له السر، قال

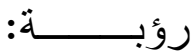

$$
\begin{aligned}
& \text { فَفَفَّ عَن أَسْر ارها بَعْد العَسَتق } \\
& \text { والعسق: المازمة ("). }
\end{aligned}
$$

و قد أثنار أبو عبيدة إلى مثل هذا المعنى وبنفس الثشاهد (ع)، ولــــ يجعلهـــا

$$
\begin{aligned}
& \text { (1) تأويل مشكل القرآن •ـ 1. } \\
& \text { (r) البقرة هب (T) }
\end{aligned}
$$

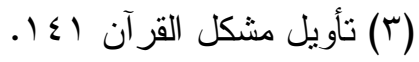

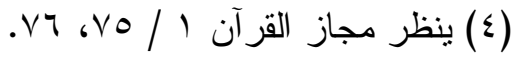


استعارة. غير أن ابن قتيبة لم يصر ح بأخذه منه، كما صر ح بما أخذه عن ابـن

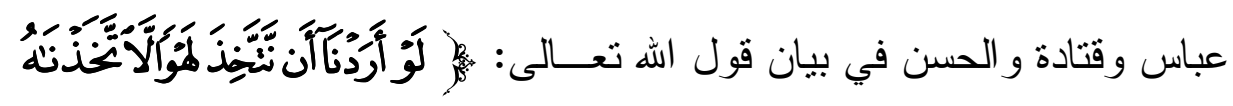

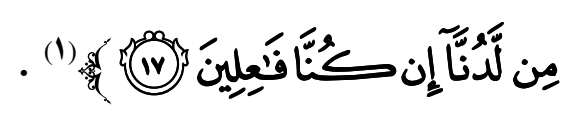
يقول: قال قتادة و الحسن: اللهو: المر أة. وقال ابن عباس: هو الولد.

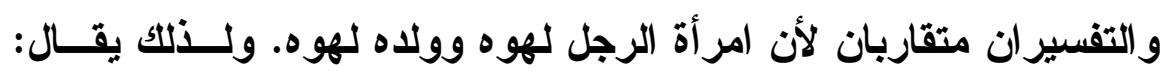

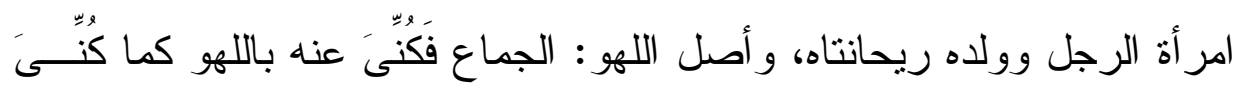
عنه بالسر (ז)... وهنا و افقهم على أنه كناية.

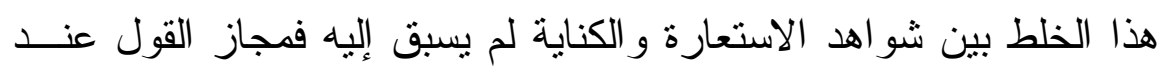

أبى عبيدة (معناه)، و الفر اء نص على معنى الكناية في قوله: او يرى أنه مدــا كنى الله عنه/ و استخل بما استخل به بعده ابن قتنية وهو قول امرئ القيس

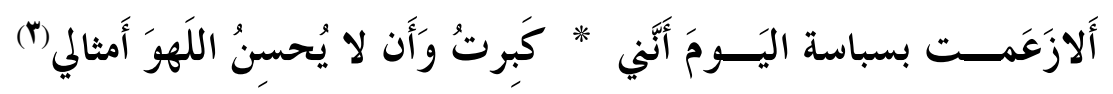

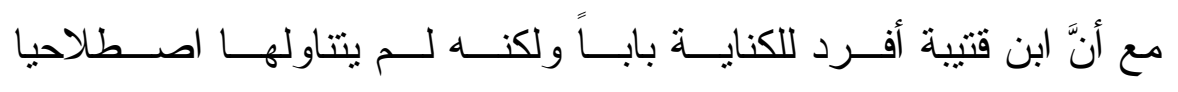
بل وقف عند الكنية التي عرفها العلماء بأنها ما بدئت بــ(أب أو أم) وســيأني ولي بيانها بعد.

و لكنه نتاول بعض شو اهدها الاصطلاحية هنا من باب وضع كلمة مكــان أخرى..، وتحدث اصطلاحيا في كتابه (تأويل مختلف الحديث). و هذا ما بدأ به الجاحظ، فكان مصدره فيه ولكنه توسع وتصرف في القول

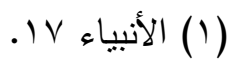

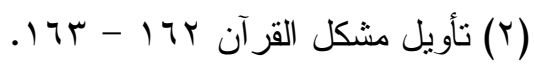

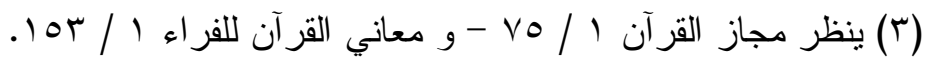


وز اد عليه انطلاقاً من قوله قبل ذلك: إذ كنت لم أقتصر على وحى القوم حتـى كثفته و على إيمائهم حتى أوضحته... وكذلك كان يعتمد في تأويله على علماء التفسير في تأسيس القو اعد البيانية

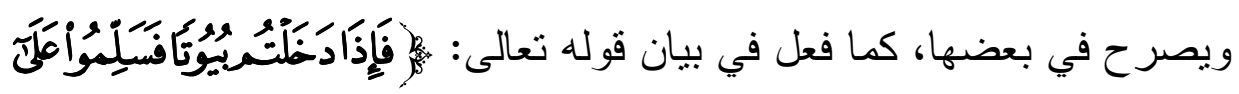

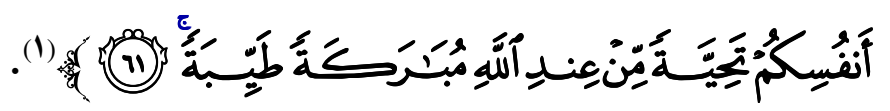

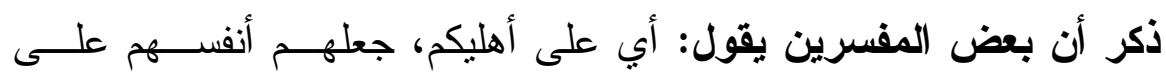
التشبيه.

وقال ابن عباس في تفسير ذلك: البيوت: المساجد، إذا دخلتها سلمت علـىى

$$
\text { نفسك و على عباد اله الصالحينه (r). }
$$

وقد وردت هذه الإشار ات و أمثالها في تفسير الصنعاني ومعــاني القــر آن للنحاس وجامع البيان للطبري وب(")... واستنبط ابن قتيبة من ذلك بيانه وقال: جعلهم أنفسهم على التشبيه وعــده من الاستعارة اتساعاً في المجاز بوضع كلمة مكان أخرى. ***

وكذلك أخذ ابن قتيبة من كلام المفسرين معنى وبنا عليه قاعدة جديدة فـي

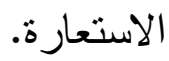

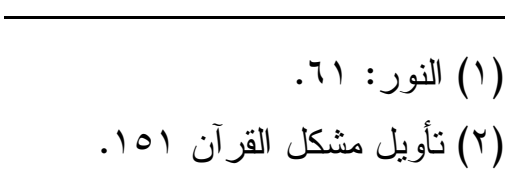

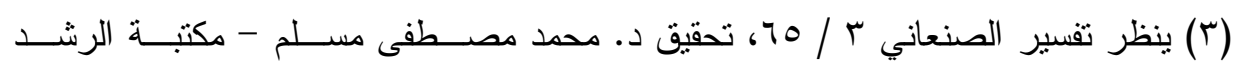

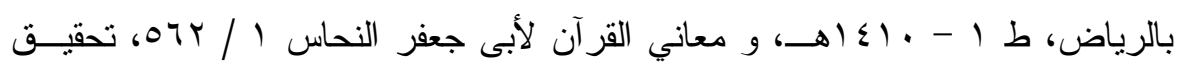

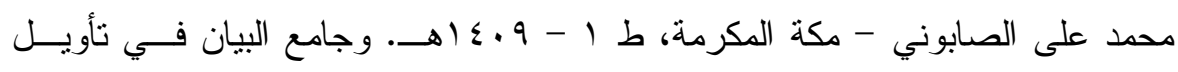

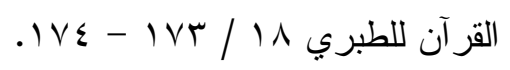




\section{الأستاذ الدكتور / السيد محمد السيد سلام}

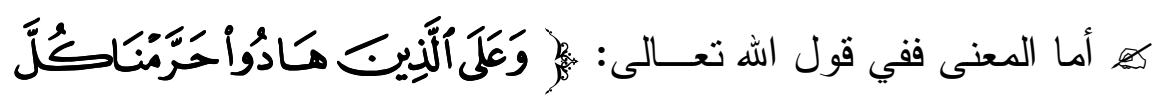

$$
\text { - (1) ذِى ظُفْرِ }
$$

قال: أبي كل ذي مخلب من الطير وكل ذي حافر من الدواب كــذلك قـــال

$$
\text { المفسرونه (") }
$$

و هذا المعنى أثنار إليه مجاهد و الصنعاني و الطبري(").

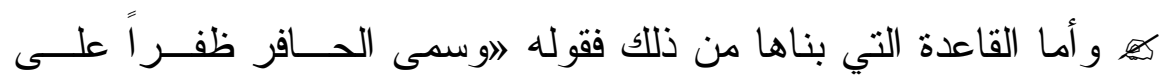
الاستعارة كما قال الآخر (جيهاء الأشجعي) وذكر ضيفاً طرقه:

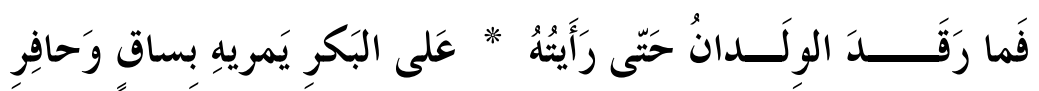

$$
\text { فجعل الحافر موضع القدم. }
$$

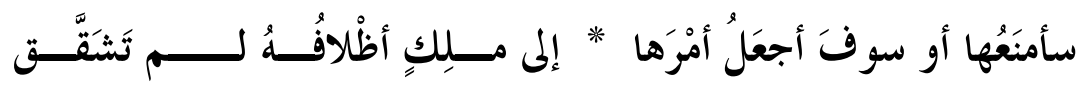
يريد بالأظلاف قدميه، و إنما الأظلاف للشاء و البقر .

والعرب تقول للرجل: 》هو غليظ المشافر نزيد الثفتين و المشافر للإبل (ع).

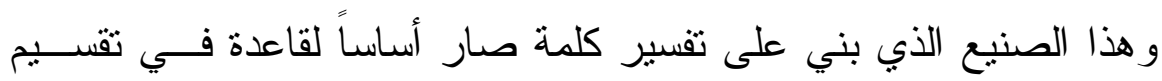

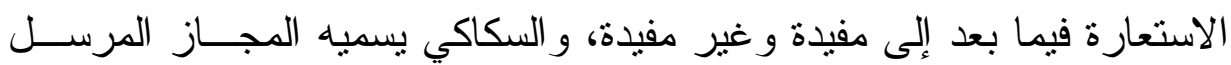
بعلاقة الإطلاق و التقبيد.

وهو لا يقصد من ور اء ذلك إلاَّ الاستدلال على استعمال كلمة مكان أخرى ولى أفادت معنى أو لم تُفد، ولكن إذا قصد بهذا الاستعمال الذم، كما قال عبد القاهر

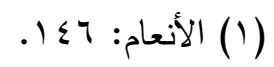

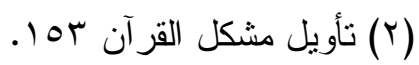

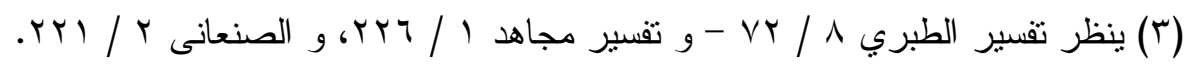

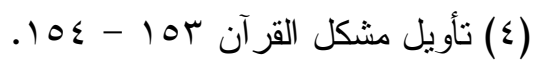


فهي استعارة مفيدة لأنها أدت معنى كان مر اداً، و هذا ما قصده ابن قتيبة بــدليل

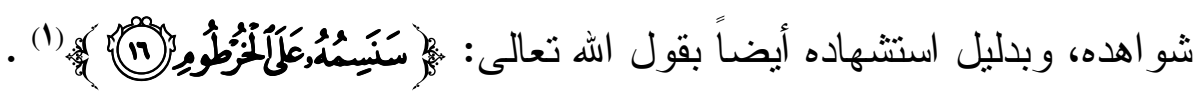

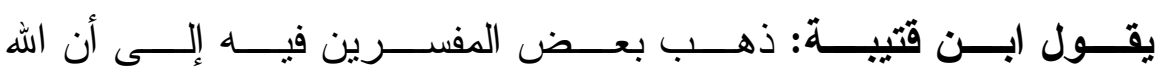

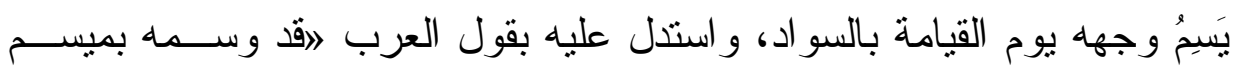

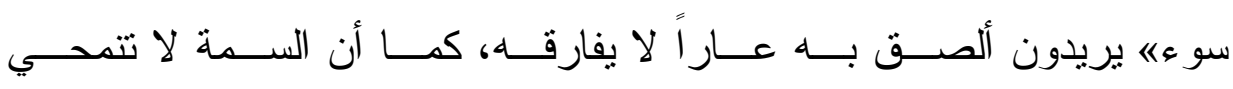

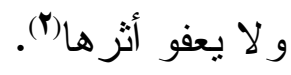

و الدليل على قصد الإهانة هنا ذكر لفظ الخرطوم مكان الأنف، وهذا يؤكد أنه يريد استعمال الكلمة مكان غير ها لمعنى يناسب المقام. كهُ وكل هذا الذي ذكره مصدره قول الفر اء اأي سنسمه سمة أهل النــار ، أي سنسود وجهه، (") ولكن لما كان المعنى يجرى على هذه الثشاكلة في كلام المفسـرين أســـده

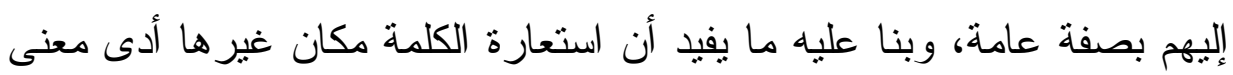

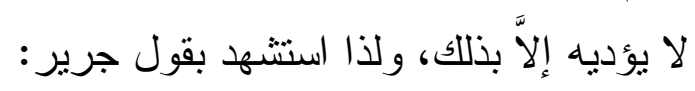

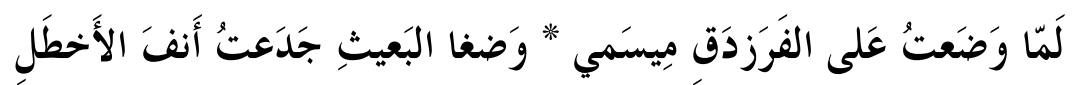

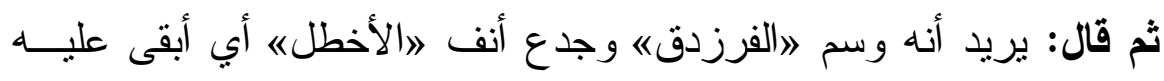

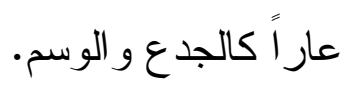
وقال أيضاً:

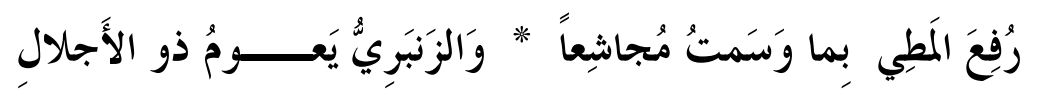

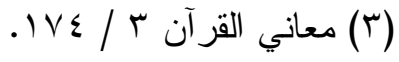


يريد أن هجاءه قد سارت به المطي و غنى به في (البر و البحر)(1).

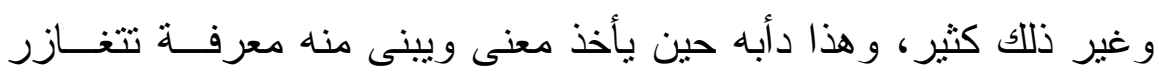
شو اهدها عنده ليتحقق له ما يريد.

\section{***}

ومن أبرز مصادره في هذا الباب أيضاً استعمالات العرب لبعض الأساليب

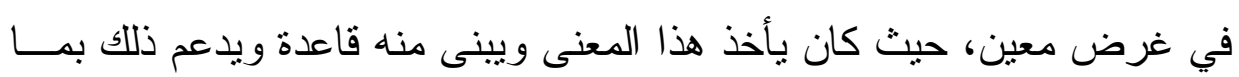
جاء في شعر هم.

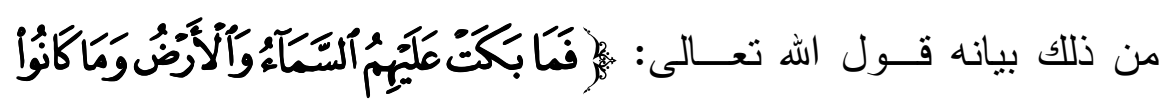

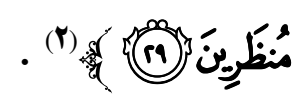

يقول: اتقول العرب إذا أر ادت تعظيم مهلك رجل عظــيم الثــــأن رفيــع

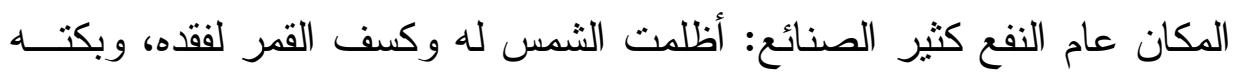

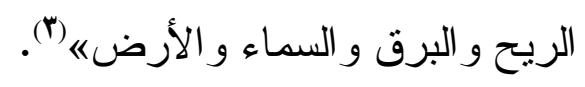

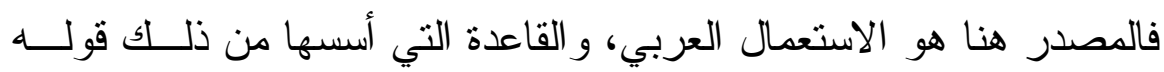
تعقيباً على هذا الكلام ايريدون المبالغة فى وصف المصيبة به، و أنها قد شلت

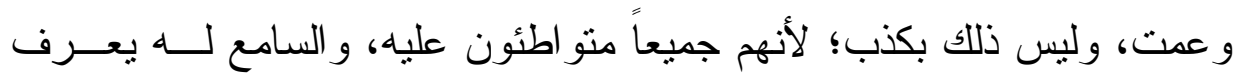

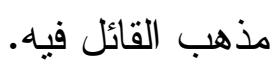
و هكذا يفعلون في كل ما أر ادوا أن يعظموه، ويستقصوا صفته، ونيتهم في

(1) تأويل مشكل القرآن 107 - 10V و و الزنبرى: العظام في السفن، و الأجلال: الثـــرع.

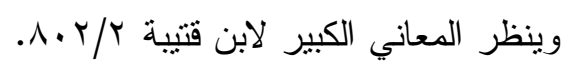

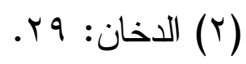

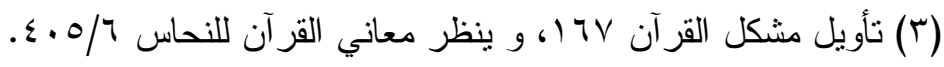


قولهم: أظلمت الثمس أي كادت تظلم، وكسف القمر أي كاد يكسف»"(1). أي أنه جعل المبالغة هي الغرض من استعارة البكاء هنا للتعظيم وليســـ كذباً، لأنها طريق متعارف بين القائل و السامع. يقصد بذلك الطريق المتعارف لمن فهم لغة العــرب و أعمـلـل عقلــهـ فــي مسالكها، و استتطق قو اعدها المغدورة في بيانها شعر أ أو نثراً. كما أنها ليست كذباً في حدود هذا المتعارف أو الذي لا يتجاوز الحدود. و مين ثَنَّ استتشهح بقول الثَاعر :

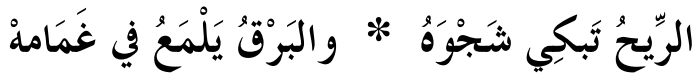
و قول الآخر:

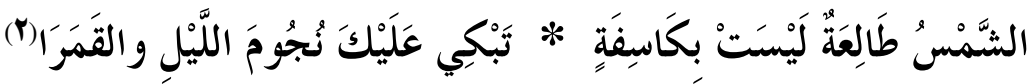
وسبب سلامة هذه المبالغة من الكذب: هذا المتعارف عنــــ العـرب فـي استعماله و غرض هذا الاستعمال. كما استتبط من ذلك قاعدة أخرى تجلت في تعليقه، وهى أن (كاد) تخفـــ تلاك المبالغة، و هذا من قو اعدها المدروسة في علم البديع.

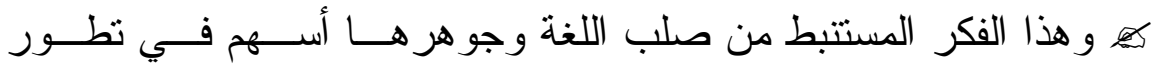

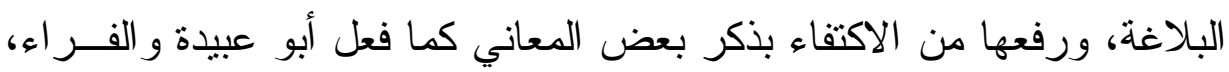

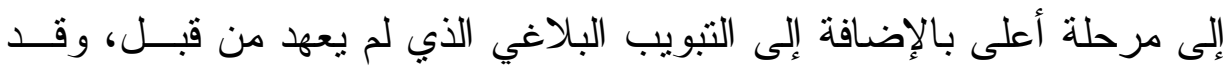
صار ذلك مهاداً للار اسات بعده. بالإصها

كهِ وبعد أن أفاض في بيان المجاز و الاستعارة، و أدخل فيها قدر اً كبيرًا من 
شو اهد غير ها كالمجاز المرسل و الكناية و التشبيه ونحو ذلك، وتجلت مصادره، وطريقة استفادته، ووجهة نظره في كل قول. بعد ذلك يعقب بأبو اب أخرى تمتُّ للبلاغة بصلة منها:

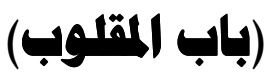

المسائل اللغوية و التصريفية التي تتاولها في هذا الباب ور اءها فر ائد بلاغية تبرز بتآلفها مع السياق و المقام، وكذا أغر اضها ها هنا أغر اض بلاغية كقولهم

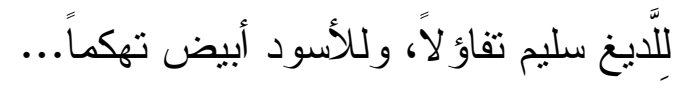

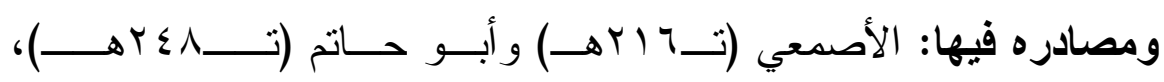

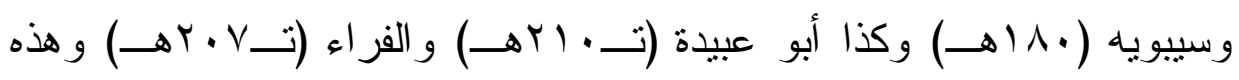
ليست مناط عملنا.

أما در استه البلاغية في هذا الباب فتمنل في التقديم و التأخير ، وذالك الـذي أبحث مصادره ورو افد مادته.

يقول ابن قتيبة: او من المقلوب: أن يقدم ما يوضِّحه التأخير ويؤخر مـــا يوضحه التقديم.

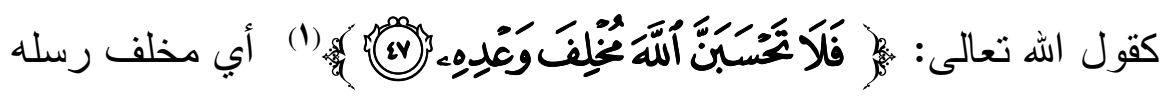

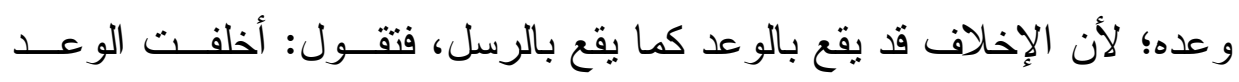

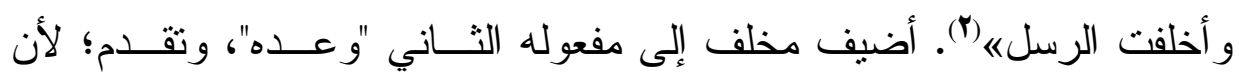
الاهتمام بنفي إخلاف الو عد أثند. ولم يطرق أبو عبيدة في مجازه للكلام في هذه الآية باباً، ولكن الذي أبــان

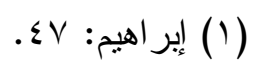

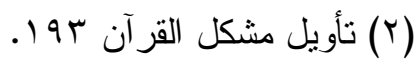




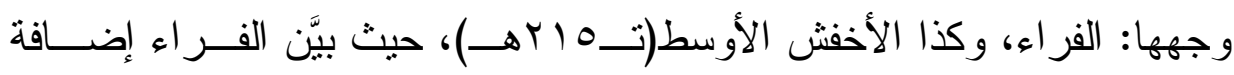

(مخلف) إلى (الو عد) ونصب (الرسل) على التأويل (1).

و أضاف الأخفش قوله: » فأضاف إلى الأول ونصب الآخر على الفعل، و لا

يحسن أن نضيف إلى الآخر لأنه يفرق بين المضاف و المضاف إليه وهــذا لا

$$
\text { يحسن ") (") }
$$

و استخل الفر اء على ما قال بما استشهد به سيبويه وهو قول الثناعر:

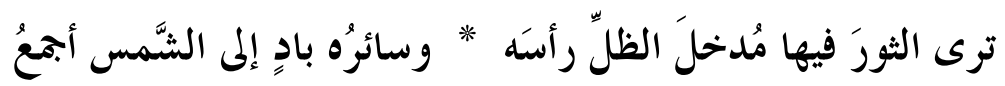

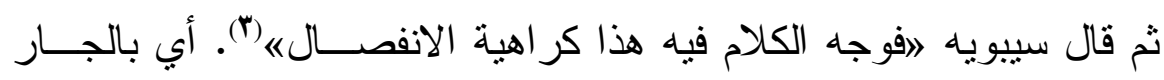

و المجرور بين المتضايفين، و الوجه: مُحخل في الظل ر أسه.

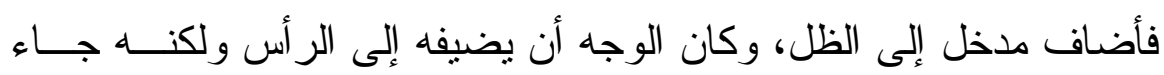

بالقلب على التوسع.

و من هذا القبيل درسه سيبويه فكان مصدر اً في هذا الباب و استدل بــنفس

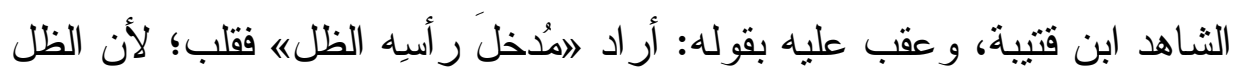

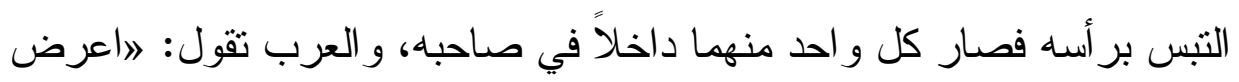

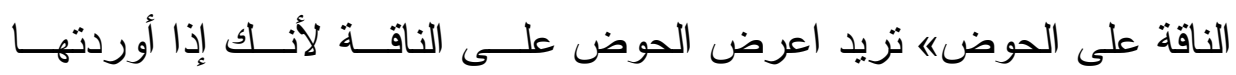
الحوض اعزرضت بكل و احد صاحبهی) (ع).

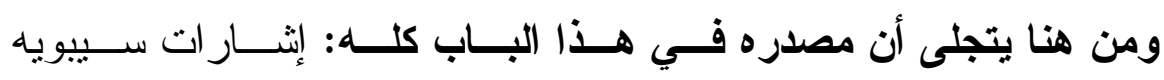

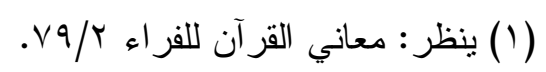

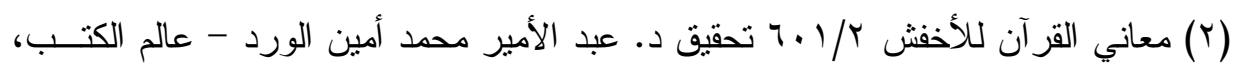

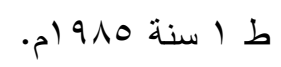

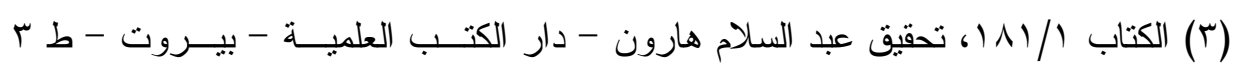

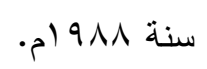

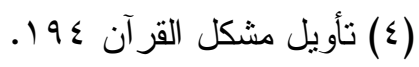




\section{الأستاذ الدكتور / السيد محمد السيد سلام}

وتوضيحات الفراء و الأخفش، بالإضافة إلى استعمالات العرب، وتأويلاته التي أعمل فيها فكره وذوقه.

و القلب عنده توسع في اللغة كما هو عند سيبويه، ومن نحا نحوه. و ابن قتيبة مع تأثزه بهؤلاء يكثز من شو اهده وتعليقاته وتدخلاته فيما يأخذ

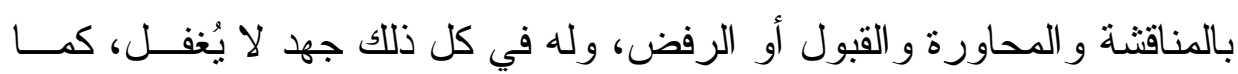
رأينا في تعليقه على شاهد سيبويه، ولذا قلت سابقاً إن فكره و استعمالات العرب وله وله أُولى مصادره.

\section{مو|قفه من أبى عبيدة في هذا الباب:}

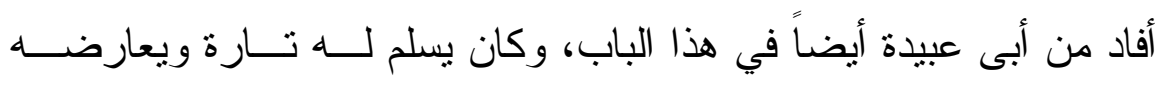

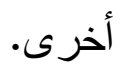

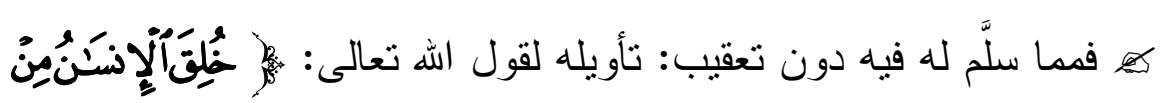

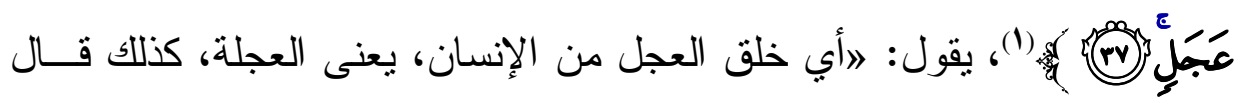

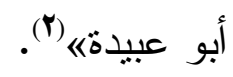

هكذا ذكره دون تعليق، بل أخذه باختصـار ؛ لأن أبا عبيدة ز اد علــى ذلـــك قوله (و العرب تفعل هذا إذا كان الثيء من سبب الثيء بدءو ا بالسبب)(").

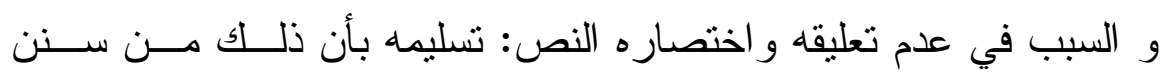
العرب، وهى مصدره الأول في بناء تأويلاته.

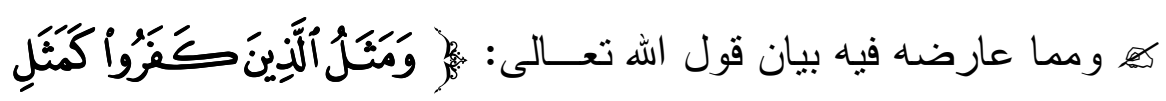

\begin{tabular}{|c|}
\hline (1) الأنبياء: Vr. \\
\hline (Y) تأويل المشكل 19 19 - 19 . \\
\hline (ץ) مجاز القرآن r / ^ז، هץ. \\
\hline
\end{tabular}




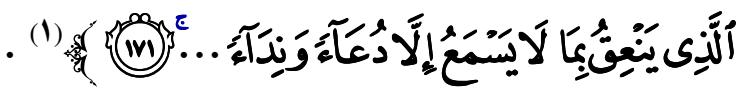

أخذ بيانها من أبى عبيدة ولم يصر ح به، بل قال:

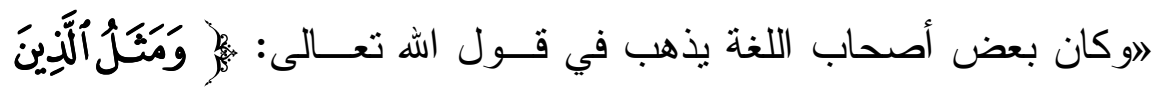

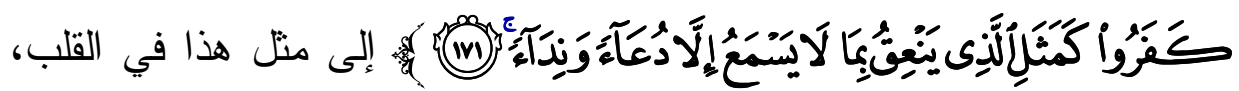
ويقول: وقع التثبيه بالر اعي في ظاهر الكلام، والمعنى للمنعوق به وهو الغنم.

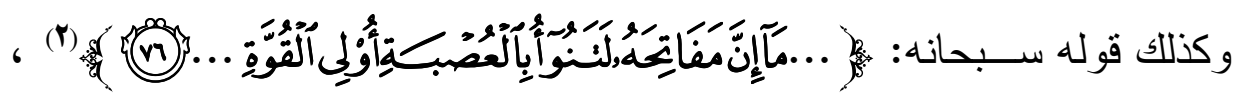
أي تتهض بها وهى مثقلةه("). أي إن العصبة تتوء بالمفاتيح، أي تثقلها.

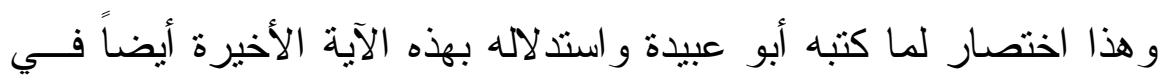
نفس المكان، و إضـافته بعضاً من أقو ال العرب كقولهم: اأدخلت القلنســوة فــي رأسي" و إنما 》أدخلت رأسك في القلنسوة) فع). ولكنه لم يرتض هذا البيان في تلك الآية الكريمة، و اعتبر القلب فيها مـن باب الغلط الذي لا يجوز في حق كلام الله سبحانه. فبعد استطر اد طويل لثو اهد هذا اللون من القلب 》الغلطه مــن القــرآن، و الثعر، يبيحه في الثعر، ويرفضه في القر آن؛ لأن الثعر اء تقلب للضــرورة،

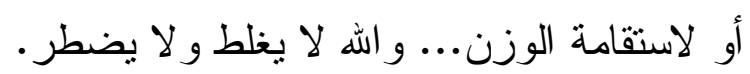

ويعلق على الآية المنقولة عن أبى عبيدة بقوله لاو إنما أر اد: ومثل الـذين

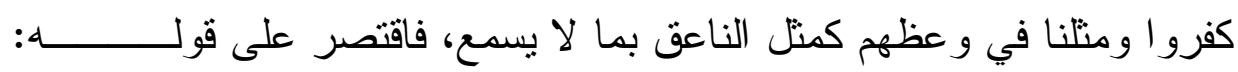

$$
\begin{aligned}
& \text { (1) البقرة: } \\
& \text { (Y) القصص: V (Y) }
\end{aligned}
$$

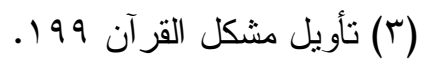

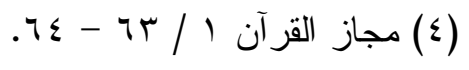




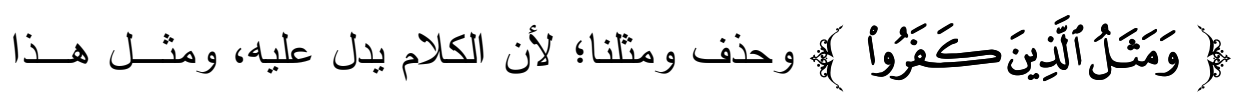
كثثر في الاختصاره.أي أنه اعتبر علة القلب الاختصار وليس الغلط.

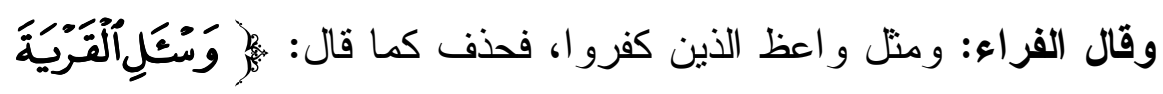

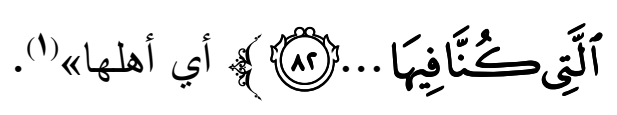

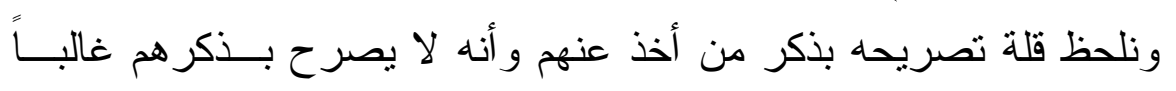

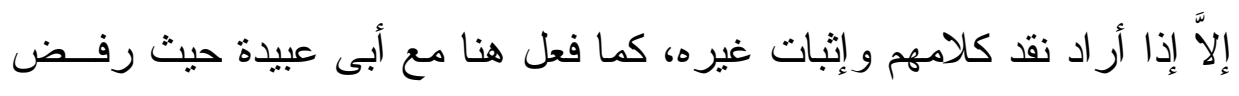

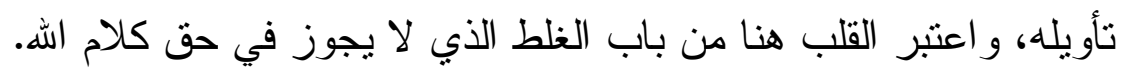

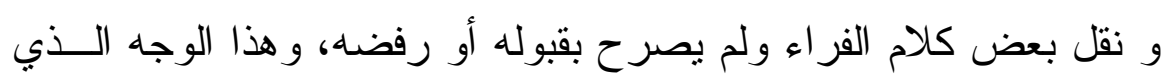

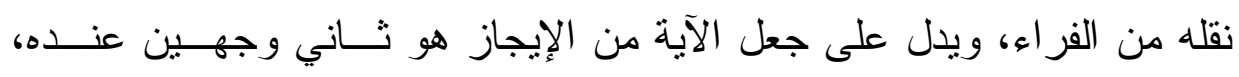

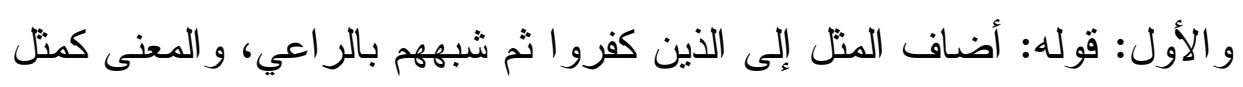

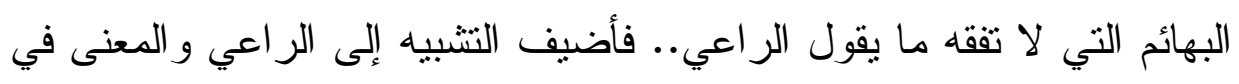

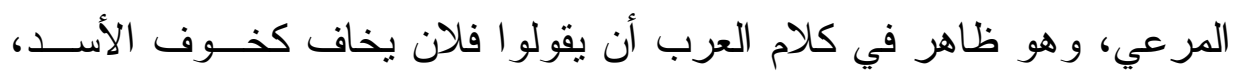

$$
\text { و المعنى كخوفه من الأسد.) (َ). }
$$

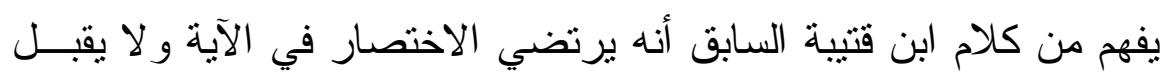

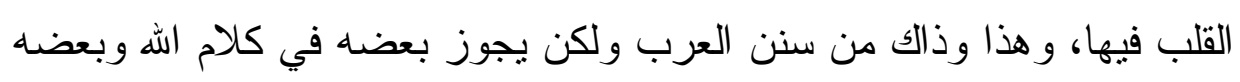
لا يجوز ، وهذا الأخير جعله غلطاً. وتلاك تسميته هو وليست من كلام أبى عبيدة و لا الفر اء وهما أبرز مصادره في بيان الثو اهد. أما بناء فكرة القلب فمصدرها عندهم جميعاً: إثنارة سييويه كما سبق فـي

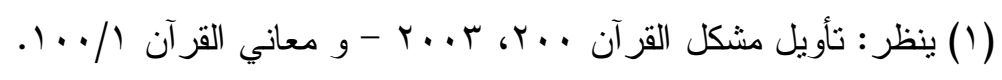

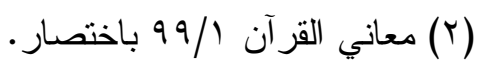


و من الأبواب البلاغية التي نص عليها ابن قتيبة فـي: (تأويـلـ مشـــل

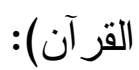

\section{(باب الإبماز)}

وسماه الحذف و الاختصار ، وهما نوعا الإيجاز كما جاء في تز اثهم بعـده

(إيجاز الحذف و إيجاز القصر ).

ومصدره الأول في هذا الباب: سنن العرب ومذاهبهم كما قـال: لاو مـنـ

مذاهبهم الاختصار إر ادة التخفيف و الإيجاز «ـ

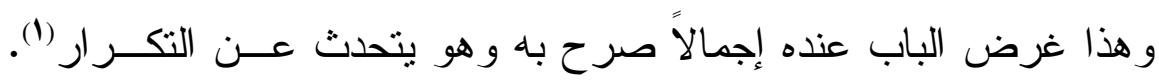

ومصدره الثاني فيه كتاب سيبويه، فهو من أسبق المصادر في هذا الباب، و أفاد

منه في ذكر الشو اهد وبعض المعاني، فقد وضع سيبويه أساسه في باب:

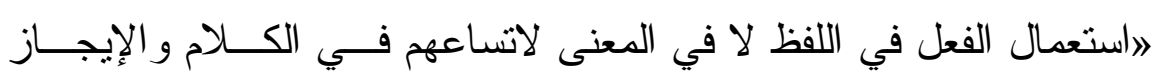

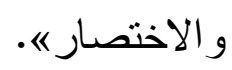

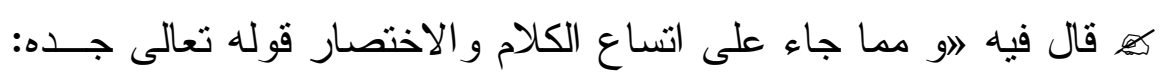

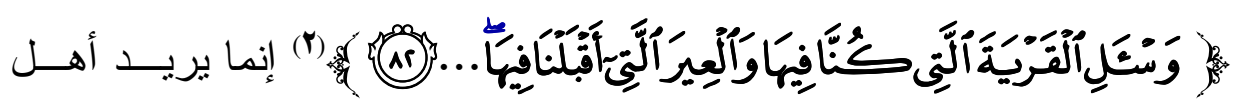
القرية فاختصر و عمل الفعل في القرية كما كان عاملاً في الأهــلـ لــو كــان ها هنا

كان هذا مصدراً لقول ابن قتيبة في طليعة هذا الباب المن ذلك: أن تحذف

$$
\begin{aligned}
& \text { (1) ينظر تأويل مشكل القرآن هبr. } \\
& \text { (r) يوسف: بن (r) }
\end{aligned}
$$

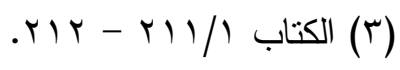




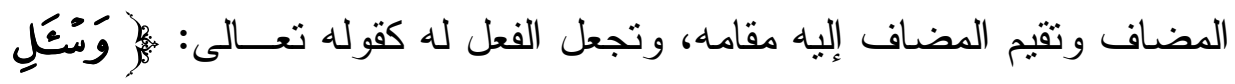

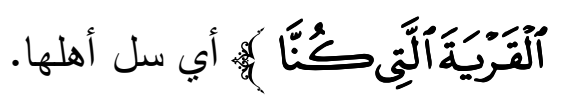

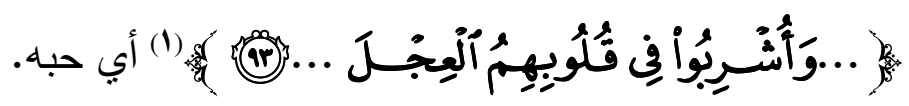

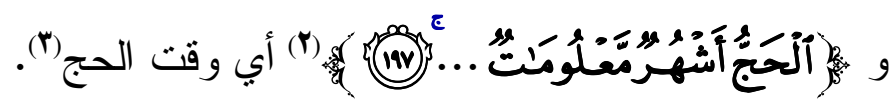

كعِ كذلك استقى ابن قتيبة التسمية و المعنى من أبى عبيدة، و هذا كثير عنده،

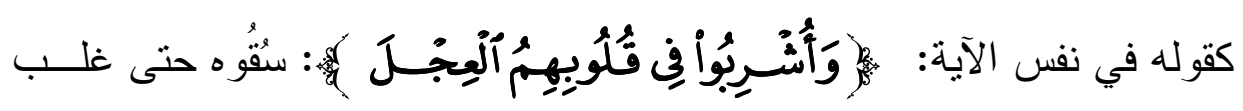

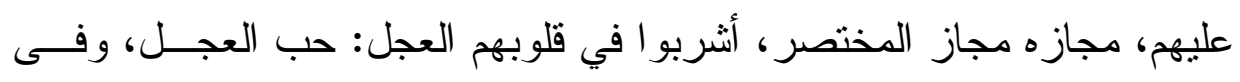

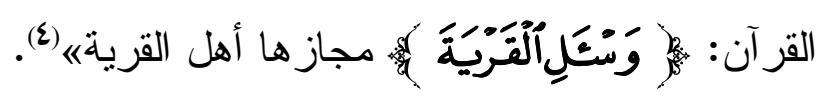

و ذكر الفر اء نفس المعاني و استشهد بما أنشده المفضل:

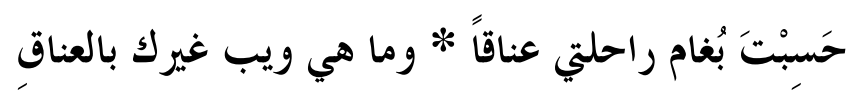

$$
\text { ومعناه: بغام عناق...(0) }
$$

وكان يبنى أغر اض حذفه من كلام أبى عبيدة و الفر اء، وقد يصرح بــذكر

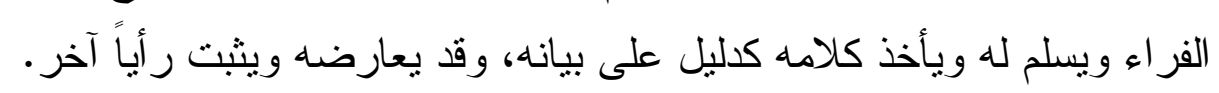

نرى ذلك في قوله: لاوقد يشكل الكلام ويغضض بالاختصار و الإضمار هـ

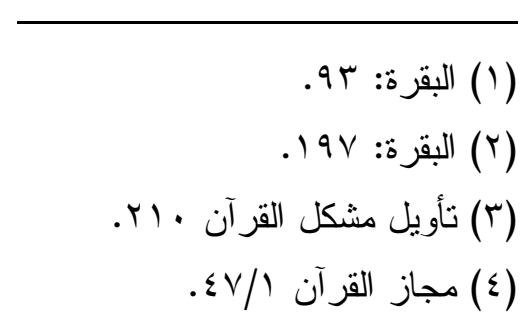

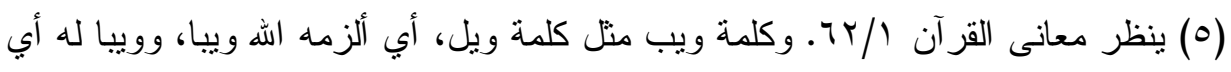

عجبا له. 


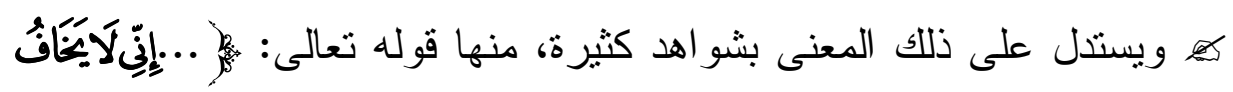

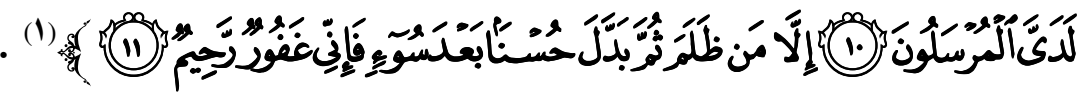
ثم يقول: لم يقع الاستثناء من المرسلين، و إنما وقع من معنى مضمر فـي

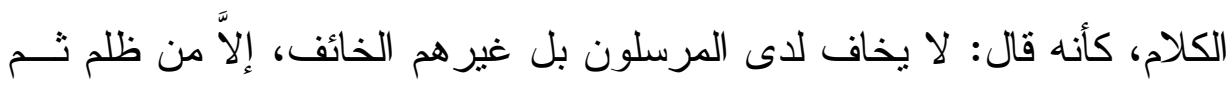

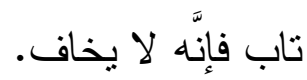
ثم يعقب عليه بقوله:

و هذا قول الفر اء، وهو يبعد؛ لأن العرب إنما تحذف من الكلام ما يدل عليـهـ ما يظهر، وليس في ظاهر هذا الكلام على هذا التأويل دليل على باطنه. والأي عندي فيه، والله أعلم: أن موسى لما خاف الثعبان وولى ولم يعقب لهب

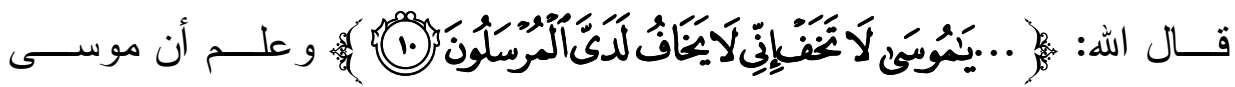

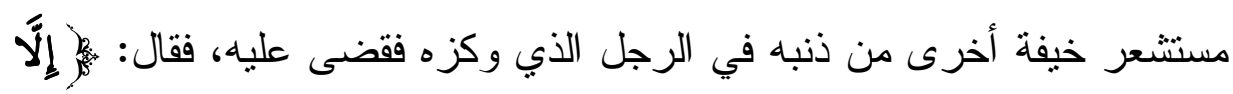

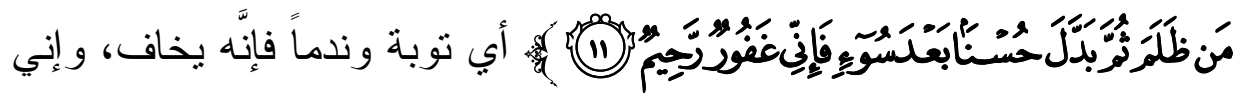
غفور رحيم" (َ)

ولو أنه نقل نص الفر اء دون اختصار أو تحريف لما وجدنا فرقاً بينهـــا، ولكنه تصرف في نصه،، وأخذ عليه ما ليس له؛ لأن الفراء ذكر في هذا الكلام وجهين، هذا الذي عقب به ابن قتيبة هو شرح الأول منهما.

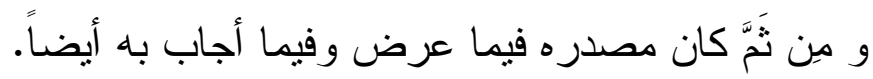
أما أبو عبيدة فكان يستتبط من معانيه هنا دون أن يصرح.

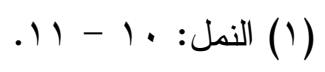

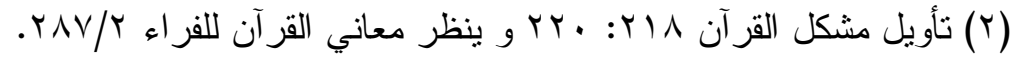


و لنأخذ من ذلك نموذجاً، يتجلى فيما يلي:

ذكر ابن قتيبة أن من دو اعي الحذف و الاختصار ״أن يأني بالكلام مبنيــاً

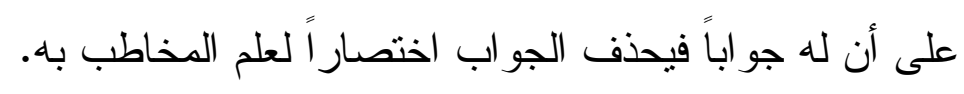

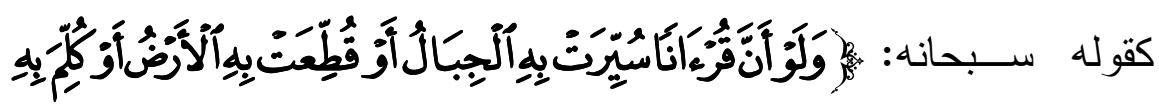

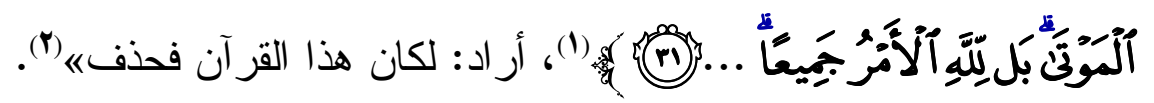

هذا نصه وتأويله، أما بناء الغرض الذي استذل عليه بهذا الثاهد وغيــره

من القرآن و الثعر فمن نص أبى عبيدة في قوله لاو العرب قد تفعل مثـلـل هـــا

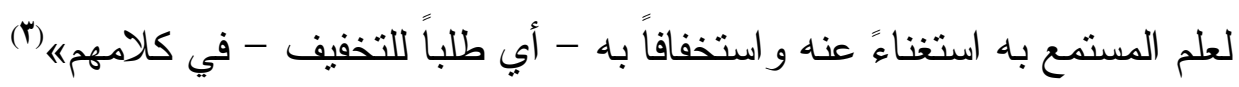
ونحوه في كلام الفر اء. ومن ثم تبين أن مصادر هذا الباب عنده: كتاب سيبويه، ومجاز القرآن لأبى عبيدة ومعاني القر آن للفر اء.

وبرز جهده في استتباط الغرض وتوضيح الغامض وتفصيل المجمل مـن بيانهم، و الإكثار من الثو اهد قياساً على ما ورد في مصادره. وتجميع هذه الثو اهد في مكان و احد تحت بابها جهد لا ينكر ، بل هو مقدمة

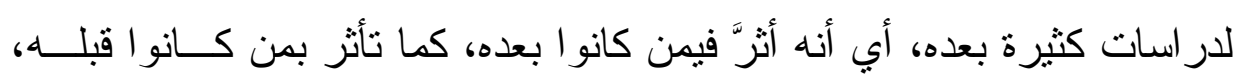

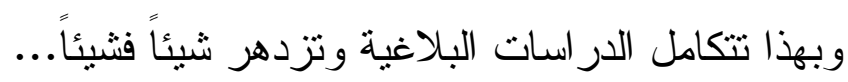
و الثو اهد التي نأثز فيها بأبي عبيدة و الفراء في باب الحذف و الاختصــار

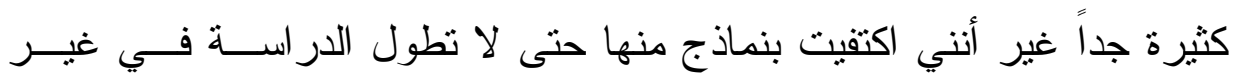

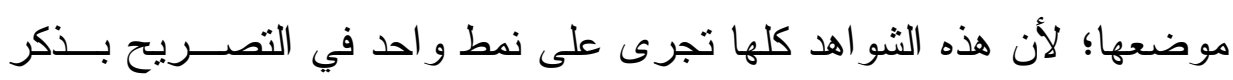
مصدره أحياناً وعدم التصريح به أخرى، وقد أخذت مــن هــذا وذالك لأبــيِّن

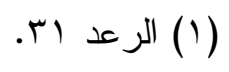

(Y)

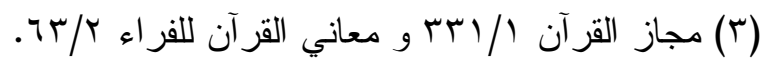


طريقته.

و المهم أن أسـاس القاعدة ذكره سيبويه، وبناء الأغر اض وتحليـلـل بعــ رض الثو اهد أفاده من أبى عبيدة والفر اء على نحو ما رأينا، واستقصاء كل الثو اهد في هذا الباب أو غيره يخرج الدر اسة من بيان مصادره إلى در اســـة شـــو اهده البلاغية وهذا مجاله أرحب.

***

أما باب

\section{(تكرار الكلام والرزيادة فيه)}

فإنَّه من أكثر الأبواب التي تخدم غرضه من تأليف هذا الكتاب وهو دفـع

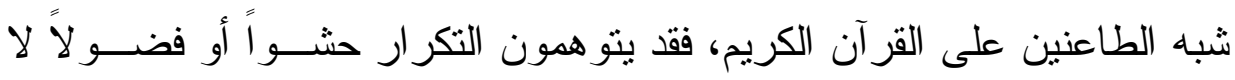
معنى له، ودر اسة هذا الباب تدحض ذللك وتفند أفكار هم الفاسدة وتـردهم عـنـ غيهم، و لا سيما إذا دعمت بما جرت عليه سنن العرب، وجلت ما في التكــر ار

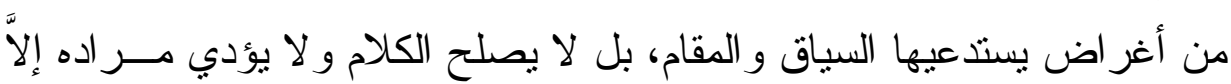

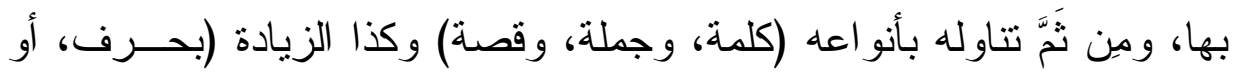
كلمة) ويكثف الكتاب عن كل ذلك مستتبطاً بعضه من بيان السابقين وموضحاً بعض ما كان مبههاً، ومفصلاً بعض ما كان مجملاً وبانياً من هذا وذالك أموراً لم تذكر من قبل على نحو ما رأينا في الأبو اب السابقة. كهِ ومصدره الأول في ذلك أيضاً مذاهب العرب وقد صرح بأن القـــــآن

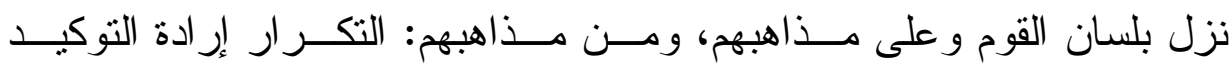

و الإفهام... (1)

كيُّ ولكن نلحظ أن در استه في هذا الباب لا تزيد في معظمها عــن مــنهج

(1) ينظر : تأول مشكل القرآن هبr. 
سابقيه كأبي عبيدة و الفر اه، وهما أكثر مصادر هما تبين خلال هذا العمل.

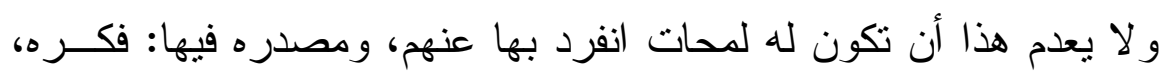

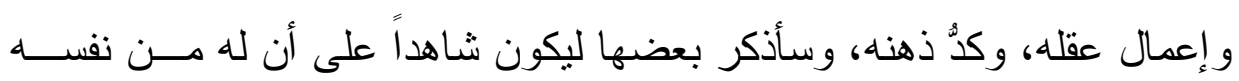

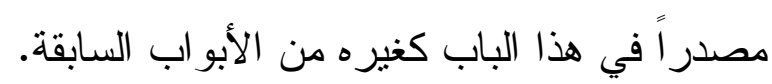

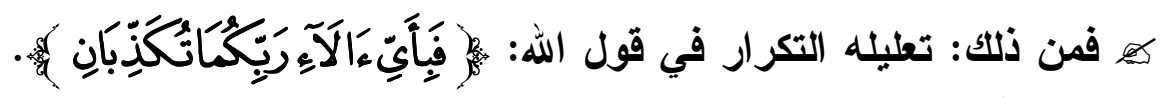
يقول: افإنَّه عدَّد في هذه السورة نعماءه، و أذْكَرَ عباده آلاءه، ونبههم على

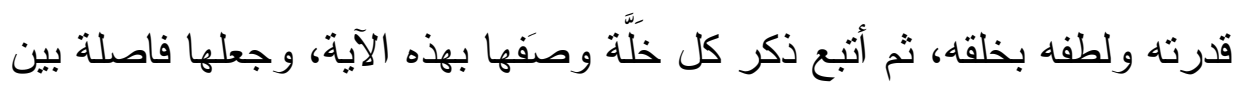
كل نعمنين، ليفهمهم النعم ويقرر هم بهاه" (1). ولم يشر أحد منهم إلى شيء من ذلك، بل هو استتباط عقلى دقيــق كـــان مستنداً للتأويلات بعده.

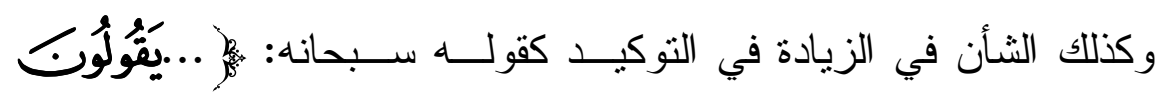

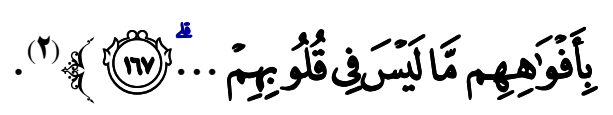

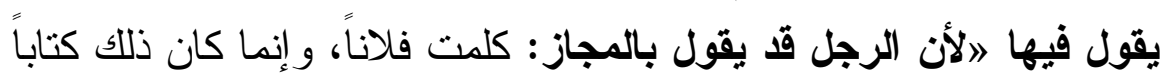

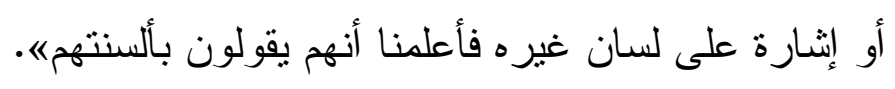
وكذلك قوله: بالمجاز و غيره الكاتب عنه (ع). يفهم من ذلك أن الزيادة هنا أفادت توكيد أنهم هم القائلون بأنفسهم ولم يقل (1) تأويل مشكل القرآن وبr و و الخلة بالفتح الخَصلة، وبالضم الصداقة، وبالكسر المودة.

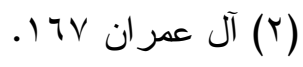
(

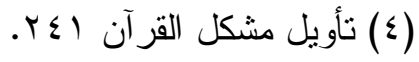


أحد عنهم، و الكاتبون بأيديهم ولم يكتب أحد عنهم، فالكلام على حقيقته و لا مجاز

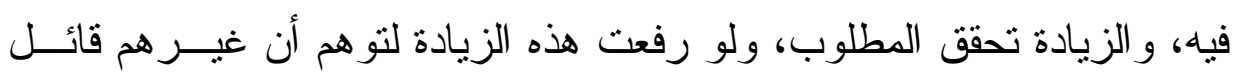
عنهم وكاتب عنهم..

ولم يتعرض أساتذة ابن قتيبة لمنل هذه المعاني، بل مصدره فــي بيانهــا فكره، و لا ريب أنه يجرى في كل أقو اله حين يستتبط ويناقش، ولكن قد يظهـر عنده ما لم يقله غيره ممن يأخذ عنهم.

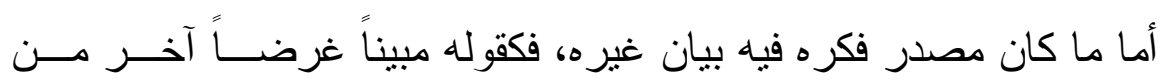

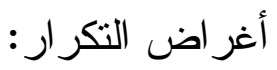

او أما تكر ار المعنى بلفظين مختلفين فلإثباع المعنى و الاتساع في اللفظ.

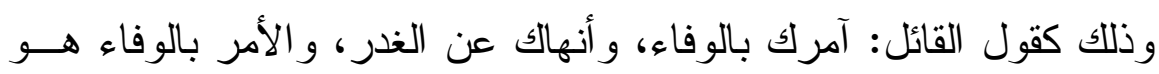

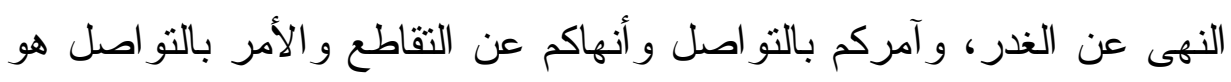

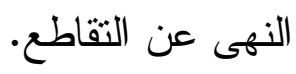

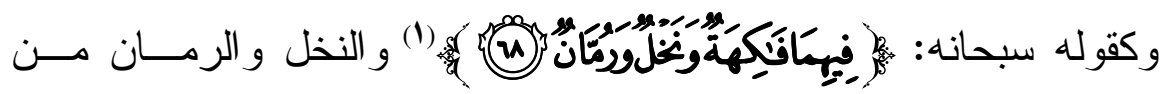
الفاكهة، فأفردهما عن الجملة التي أدخلهما فيها؛ لفضلهما وحسن وقعهما.

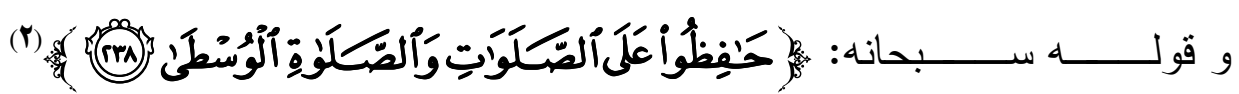
وهى منها، فأفردها بالذكر تز غيباً فيها، ونتديداً لأمر ها.... وهذا الذي عرف فيما بعد بذكر الخاص بعد العام.

$$
\begin{aligned}
& \text { (1) الرحمن: } 71 .
\end{aligned}
$$

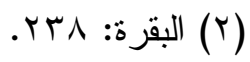

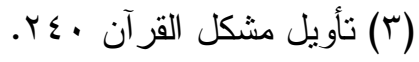


ولو تأملنا في تفسير الفراء(1) لآية الرحمن لوجـــنا لمحــات و إثـــار ات، تفصيلها بيان ابن قتيبة هذا، وقد ذكر الفر اء الآية الثانية في نفس الموطن مسن سورة الرحمن. - ماك.

ولكن ابن قتيبة حين فصيَّل إثثارة الفر اء لم يشرحها بل اســتخرج معرفــة جديدة بوضعه لهذا العنوان وبناء الثو اهد التوضيحية له، حتى صـار المعنى له

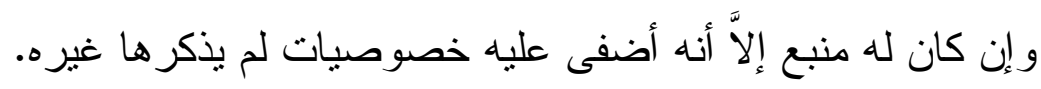

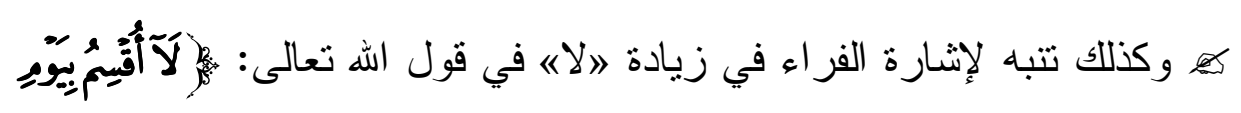

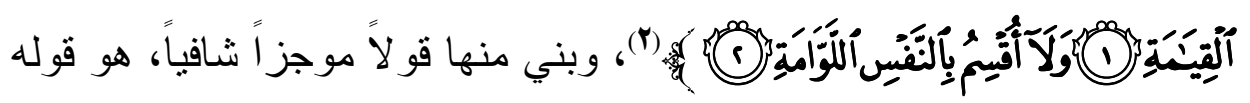

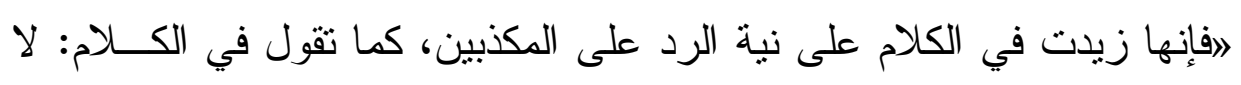
و الله ما ذالك كما تقول، ولو قلت

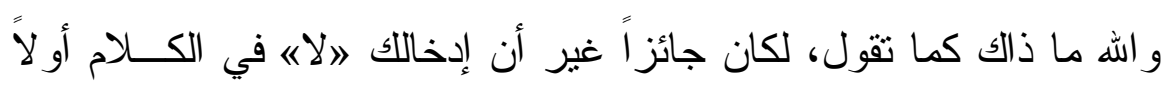
أبلغ في الرده"(")، وكلام الفراء يعنى أن "لا" جاءت ردا لكلام مضى، ولو ألقيت "لا"لم يكن بين اليمين التي تكون جو ابا و التي تستأنف فرق. و هذه المسألة من أكثر المسائل التي شغلت النحويين و المفسرين وكثـرت حولها

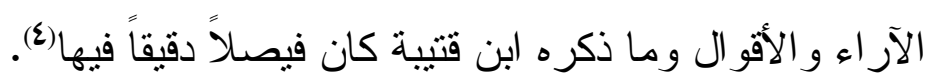
كيَّ بقى من الأبواب البلاغية التي ذكرها ابن قتيبة في هذا الكتاب:

$$
\begin{aligned}
& \text { (1) ينظر معاني القرآن ץ / 119. }
\end{aligned}
$$

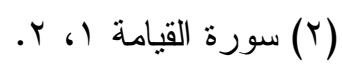

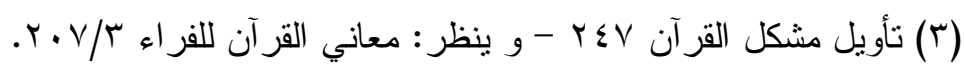

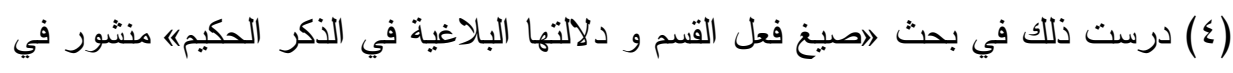

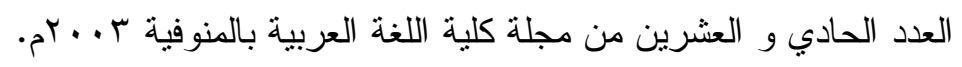




\section{باب الكنالية والتصريني}

و لم يتحدث فيه عن الكناية الاصطلاحية المعروفة بــكر الثــيء و إر ادة لازم معناه، بل جاء حديثه فيها عن الكنية كأن تكنى عن اسم الرجل بالأبوة، أو

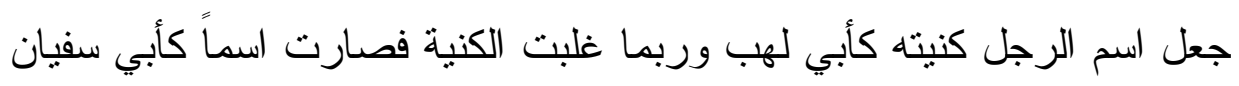
و أبى طالب... وذكر أثنياء من هذا القبيل، ثم عطف عليها التعريض وكأنه فرع منها، أو عنها. فقال: ومن هذا الباب 》التعريضه" و العرب تستعمله في كلامها كثير اً فتبلغ إر ادتها بوجه هو ألطف و أحسـن من الكثف و التصريح، ويعيبون الرجل إذا كان يكاشف في كل شيء ويقولون:

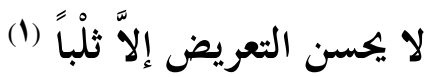

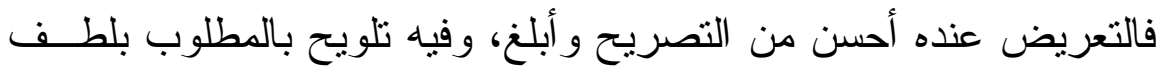
وموار اة، وفيه مخرج من الكذب أيضاً.

ومصدره الأول في ذللك وروده في كلام الله وكلام العرب كما استتد فـي ملي بيانه على إثنار ات المفسرين القدامى، وصرح بذلك في قوله الاوروى المنهال عن

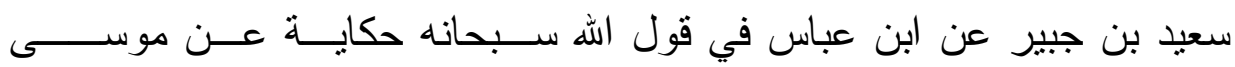

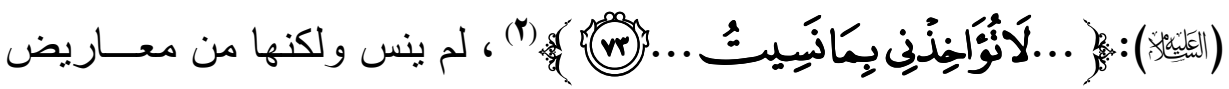
الكلام. ثم علق عليه بقوله: أراد ابن عباس أنها لم يقل: إني نســيت فيكـون كاذبــاً، ولكنــهـ قــال: 
لا تؤُ اخذني بما نسيت، فأو همه النسيان، ولم ينس ولم يكذب. ولهذا قيل: إن في المعاريض عن الكذب لمندوحة.

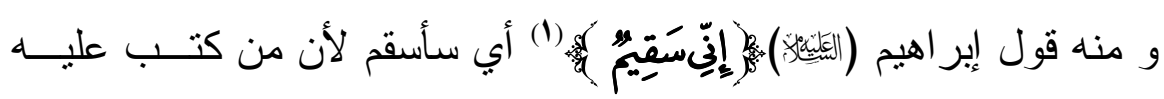
الموت فلا بد أن يسقم... فأو همهم إبر اهيم بمعاريض الكلام أنه سقيم عليل، ولم

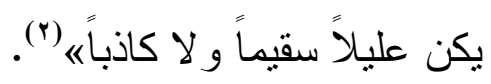
فهذه الإشار ات كانت مصدر اً له بالإضافة إلى ما ذكره الفر اء في بيان قوله

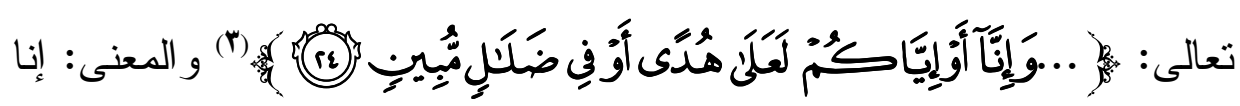

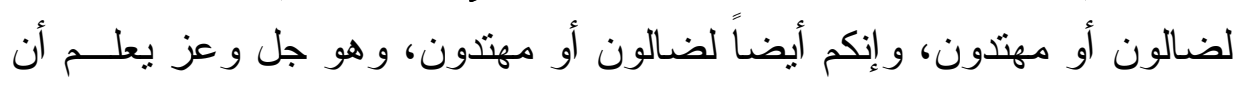
رسوله المهتدى وأن مخالفه الضال، و هذا كما تقول للرجل يكذبك ويخالفك: إن أحدنا لكاذب و أنت تعنيه، فكذبته من وجه هو أحسن من التصريح كــذلك قـال

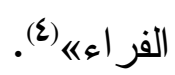

وهذا كلام الفر اء كما صر ح به ولم ينص الفراء على ذكر التعريض كمـــا نص ابن عباس، ولكنه يفهم من معنى كلامه. وقد وفق ابن قتيبة بين هذه الأقاويل و انتهى إلى ونى

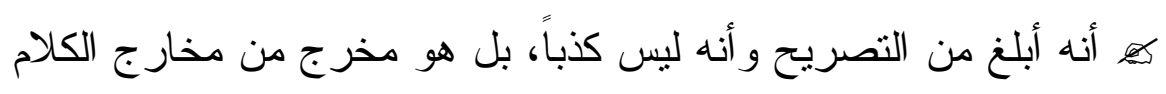

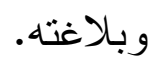
و قد صرح به الفر اء في موطن آخر أخذه منه ابن قتيبة في بيــان قــول

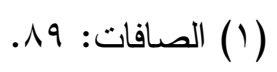

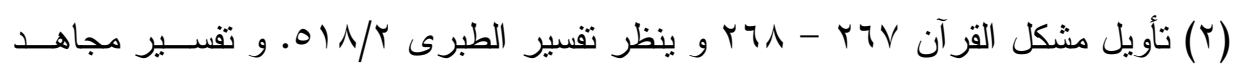

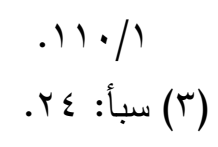

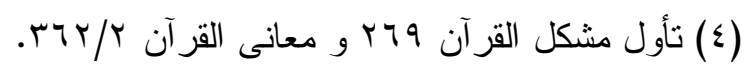




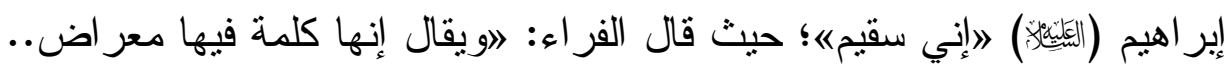
«") أي أن كل من كان في عنقه الموت فهو سقيم، و إن لم يكن به حين قالهــا سقم ظاهر ، وهو وجه حسن.

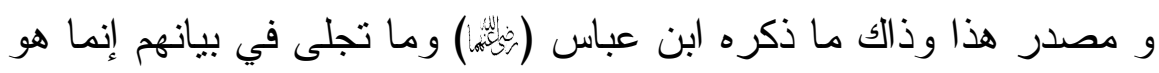
توضيح للمعنى وبيان وجه حسنه.

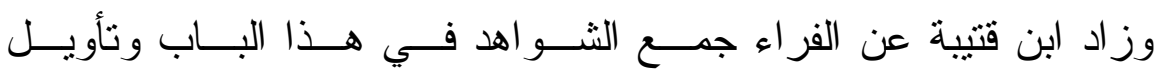
ما يحتاج إلى تأويل وبيان ما تحتمله من وجوه.

\section{***}

و من خلال هذه الدر اسة تجلت مصادر ابن قتيبة البلاغية في تأويل مشكل

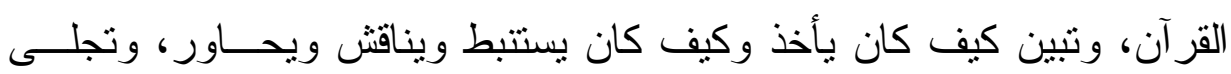

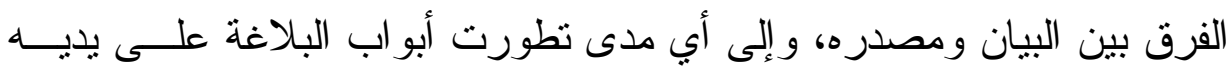

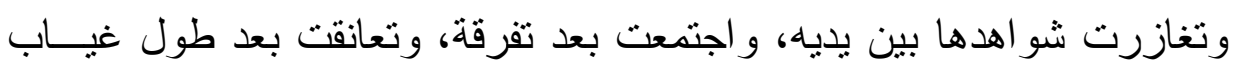
وتر ابطت أبو ابها وتتاسقت -إلى حدٍ ما- مسائلها وكانت ركيزة للار اسات بعده. و تلك هي أبو اب البلاغة التي وقف عندها، و التـي أردت كثــــ مصـــادر ها ومعرفة منابعها.

وذكر بعدها باباً آخر جمع فيه ألو اناً مــن العناصــر البلاغيــة المختلفـــة

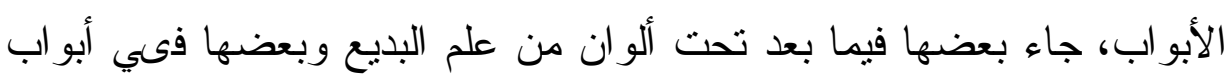
من علم المعاني، وسمى هذا الباب (باب مخالفة ظاهر اللفظ معناه).

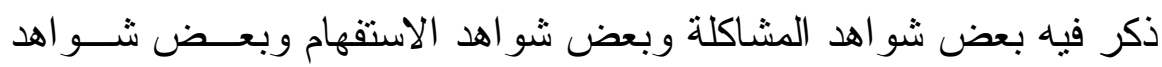
المجاز العقلي، وبعض شو اهد خروج الكلام على خلاف مقتضــى الظــاهر .. ونحو ذلك.

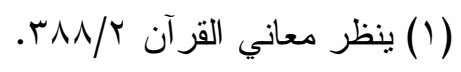


و جهده فيها يتجلى في وضع عناوين تفسّر ما تحتمله هذه الثو اهد.

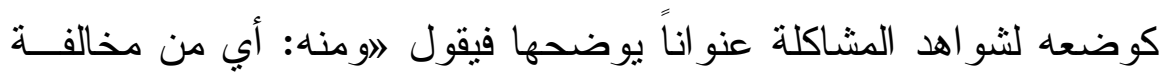
ظاهر اللفظ معناه: الجزاء عن الفعل بمثل لفظه و المعنبـــان مختلفــان، وكــــا

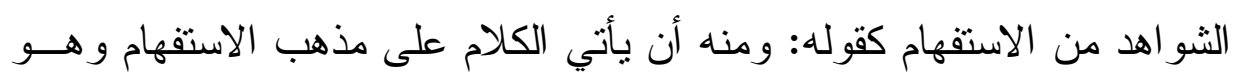
تقرير .. وكذا وهو توبيخ، وكذا في الأمر وهو تهديد وهكذا.. وليس له شرح أو لهاب توضيح إنما هي عناوين تفسر المعنى المطلوب. وقد بحثت عن هذه الضو ابط في نز اث من سبقوه فتبين أنها من اختيار اته و استتباطاته العقلية، وقد صارت ركيزة في الدر اسات البلاغية بعده.

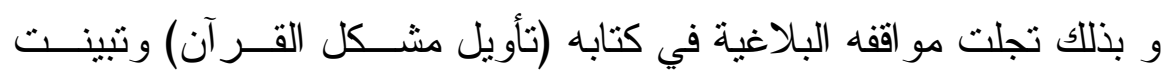
مصادر ها وما له فيها من جهر وفكر مون.

وأسأل النّ التوفيت والسراء. 


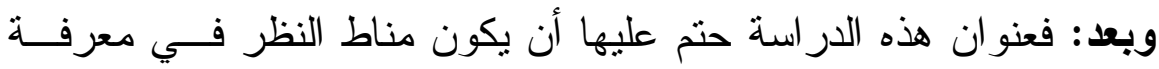
المصـادر البلاغية التي شكلت عقل ابن قتيبة وهو يفكر ويبحث، وكيــف كــان يتعامل معها حين يستتبط منها أو ينقل عنها، هل كان يختصــر أو يضــيف أو يسلم أو يناقش أو ينقد ويعارض، ونحو ذللك مما قامت عليه تلاك الدر اسة،لتكون نبر اسا للدارسين في معرفة مصادر كل عالم وطريقة تفكيره،وطريقة التعامـلـل مع ذلك، وقد تبين منها: المباحث البلاغية التي اهتم بها، و التي كان بناء عليها يعالج قضايا عقديــة في صورة بيانية، و الطريقة التي كان يوضـح بها إثـــار ات غيــره، و غــز ارة الثو اهد في المسألة الواحدة وتجلية الفكرة بصورة تجعلها خالصة لله، و استتاده في بناء أفكاره على مذاهب العرب في كلامهم وسنن بيانهم، وقلما كان يثــير إلى من أخذ عنه، وقد علل ذلك بأنه كان يتصرف ويزيد وينقص ويقدم ويؤخر

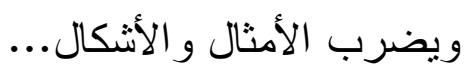
ومِن ثَمَّ تجلت في بيانه ضو ابط جديدة، و أفكار لم يسبق إليها لأنه أعمـلـل

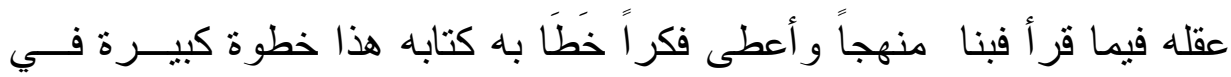
تطور البلاغة، ونقلها إلى مرحلة أعلى سواء من جهة التبويب أو مــن جهـــة تحليل الثو اهد، و استخر اج النتائج، ووضع العناوين لبعض الثـــــ اهد ليتضــح المر اد منها.

وقد انتهيت إلى أن بيانه ليس صورة من مصـادره، بل أخذ شــكلاً آخــر، و أفاد معرفة جديدة كانت أرضاً لمن جاء بعده.

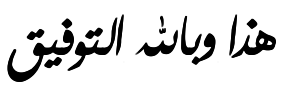

\section{أ.د. السيد هممد سلام}




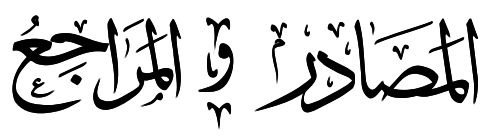

1- أثثر القرآن في تطور النقد العربي إلى آخــر القــرن الرابــع الهجـــي، د. محمد زغلول سالام، الطبعة الثالثة - دار المعارف.

r- أثر النحاة في البحث البلاغي، د. عبد القادر حسين - دار نهضة مصر . r- أدب الكاتب لابن قتيبة، دار صادر بيروت لو 9 ام. ع - البلاغة تطور وتاريخ، د. شوقي ضيف، دار المعارف.

0- البيان العربي، د. بدوى طبانة، مكتبة الأنجلو الطبعة الر ابعة ه7 97 (م.

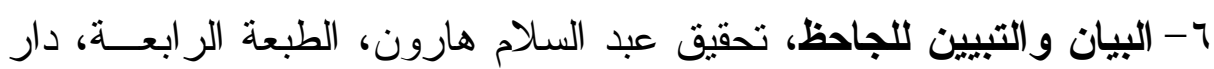

(الفكر

-V الحيوان للجاحظ، تحقيق عبد السلام هارون، طبعة الحلبي. ^- الكامل في اللفة والأدب للمبرد، تحقيق محمد أبو الفضـــل إبــر اهيم، دار النهضة.

9- الكتاب لسيبويه، تحقيق عبد السلام هارون، دار الكتب العلمية. • ا- الكشاف للزمخثري، دار المعرفة بيروت. 1 1- المقاييس البلاغية عند الجاحظ في البيان و التبيين، د. فوزي عبد ربــه، لئه

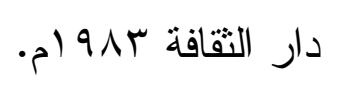

r إنتأويل مشكل القرآن، ابن قتيبة، شرحه ونشره السيد أحمد صقر ، المكتبة

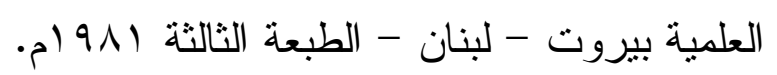
r ا - تفسير الصنعانى، تحقيق د. مصطفى مسلم محمد، مكتبة الرشد بالرياض

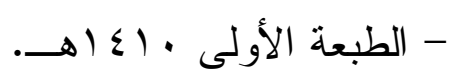


ـ ا-تفسير سفيان الثوري، دار الكتب العلميــة، بيــروت الطبعــة الأولــى $\rightarrow 1 \leqslant \cdot r$

1 - تفسير غريب القرآن لابن قتيبة، شرح ومر اجعة الثيخ إبر اهيم محمـــ

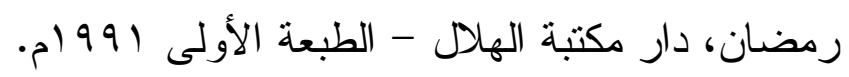

7 ا - تفسير مجاهد، تحقيق عبد الرحمن الطاهر محمد السورتي - المنشور ات

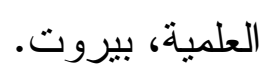

IV 1 ا-مجاز القرآن لأبى عبيدة، د. محمد فؤ اد سزكين - الخانجي بالقاهرة.

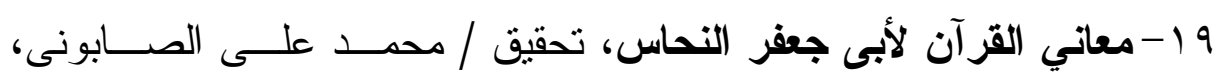

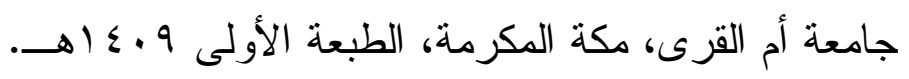

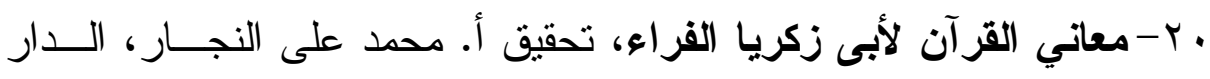
المصرية للتأليف و التزجمة. ا Y-معاني القرآن للأخفش، تحقيق د. عبد الأمير محمد أمين الورد - عــالم الكتب - الطبعة الأولى 910 ام. 
الأستاذ الدكتور / السيد محمد السيد سلام

دليل الدراسة

\begin{tabular}{|c|c|}
\hline الصفحة & الموضوع \\
\hline 0 & 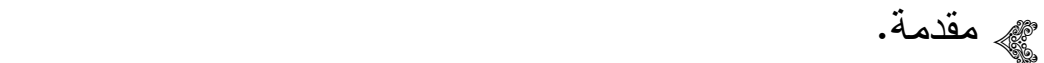 \\
\hline V & 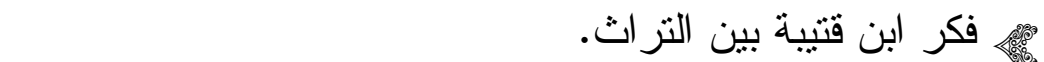 \\
\hline$\Lambda$ & 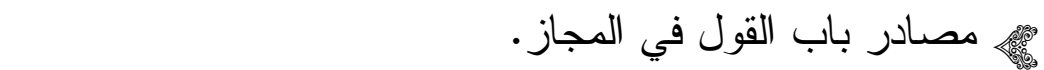 \\
\hline$\wedge$ & 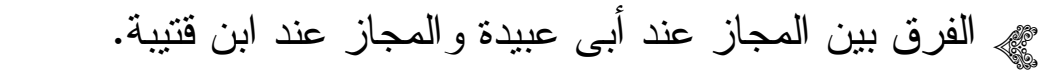 \\
\hline 9 & 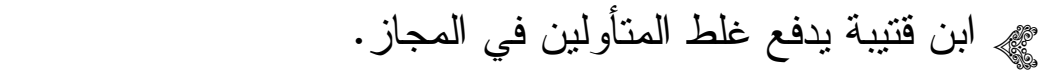 \\
\hline 1. & 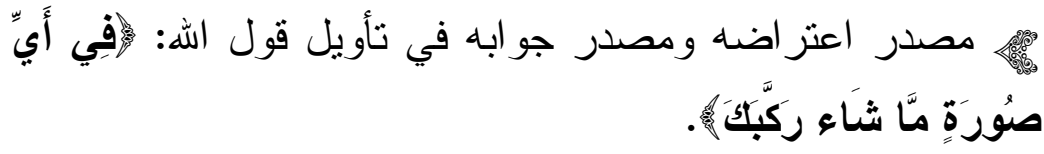 \\
\hline 11 & ذللك. \\
\hline 11 & 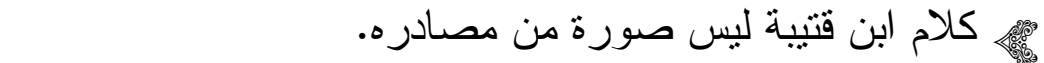 \\
\hline Ir & 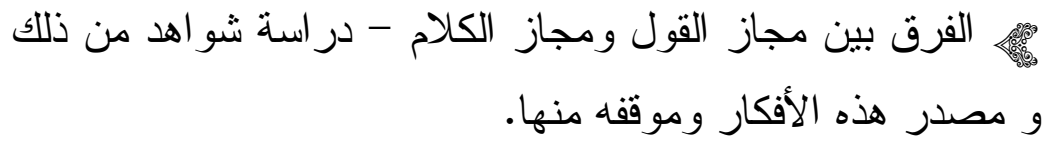 \\
\hline $1 \varepsilon$ & \\
\hline
\end{tabular}




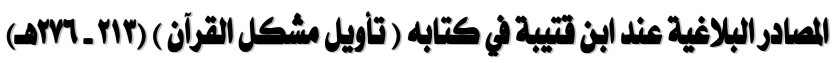

\begin{tabular}{|c|c|}
\hline 10 & 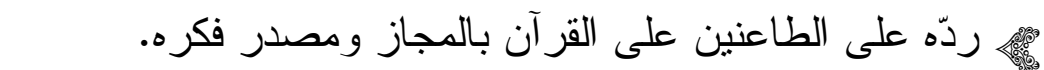 \\
\hline iv & 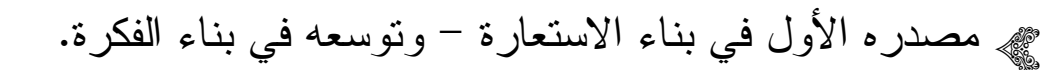 \\
\hline 19 & 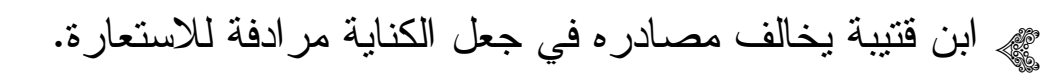 \\
\hline r & 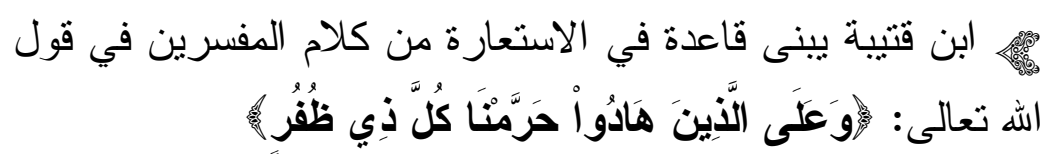 \\
\hline$r r$ & إ: إدادته من الفر اء في هذا الباب. \\
\hline r纟 & ، الاستمداد من صلب البيان العربي يخرج المبالغة من الكذب. \\
\hline rq & مصـادره في باب (المقلوب)، كلمة سيبويه أسـاس في بناء هــذا \\
\hline rᄉ & 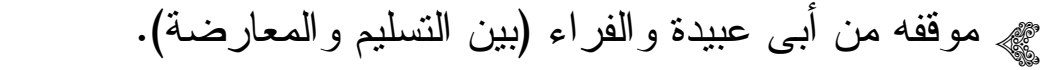 \\
\hline r & 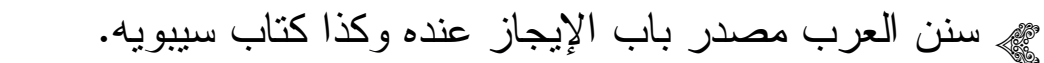 \\
\hline rr & 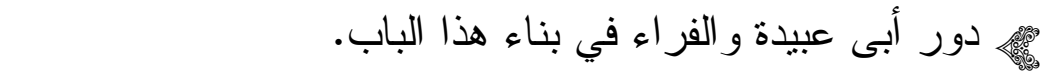 \\
\hline ro & 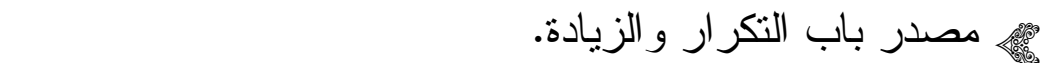 \\
\hline rq & \\
\hline rᄉ & 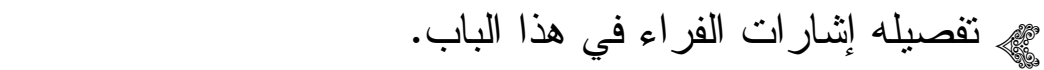 \\
\hline
\end{tabular}


الأستاذ الدكتور / السيد محمد السيد سلام

\begin{tabular}{|c|c|}
\hline$r q$ & 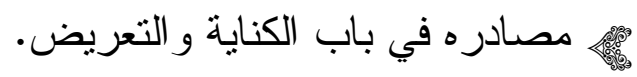 \\
\hline$\varepsilon r$ & كاتمة. \\
\hline$\varepsilon \varepsilon$ & . \\
\hline$\leqslant 7$ & , 通 \\
\hline
\end{tabular}

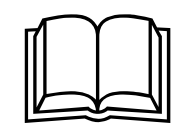

بي 


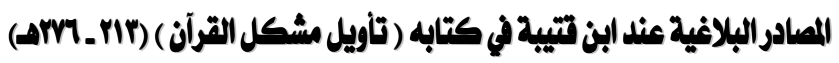

$-\leqslant 9$. 
